\title{
Regiospecific Positioning of Palmitic Acid in Triacylglycerol Structure of Enzymatically Modified Lipids Affects Physicochemical and In Vitro Digestion Properties
}

\author{
Hyeon-Jun Chang and Jeung-Hee Lee * \\ Department of Food and Nutrition, Daegu University, Gyeonsan 38453, Korea; chj931116@naver.com \\ * Correspondence: jeunghlee@daegu.ac.kr; Tel.: +82-53-850-6836
}

check for updates

Citation: Chang, H.-J.; Lee, J.-H. Regiospecific Positioning of Palmitic Acid in Triacylglycerol Structure of Enzymatically Modified Lipids Affects Physicochemical and In Vitro Digestion Properties. Molecules 2021, 26, 4015. https://doi.org/10.3390/ molecules26134015

Academic Editors: Marcin A. Kurek and Ryszard Amarowicz

Received: 7 April 2021

Accepted: 26 June 2021

Published: 30 June 2021

Publisher's Note: MDPI stays neutral with regard to jurisdictional claims in published maps and institutional affiliations.

Copyright: (c) 2021 by the authors. Licensee MDPI, Basel, Switzerland. This article is an open access article distributed under the terms and conditions of the Creative Commons Attribution (CC BY) license (https:/ / creativecommons.org/licenses/by/ $4.0 /)$.

\begin{abstract}
Tripalmitin-(PPP, 81.2\%), 1,3-dipalmitoyl-2-oleoylglycerol-(POP, 64.4\%), 1,2-dipalmitoyl3-oleoylglycerol-(PPO, 86.5\%), and 1,3-dioleoyl-2-palmitoylglycerol-(OPO, 50.2\%)-rich lipids with different regiospecific positions of palmitic acid $(\mathrm{P})$ were synthesized via acetone fractionation and lipase-catalyzed acidolysis, and their physicochemical and hydrolytic characteristics were compared. Triacylglycerols (TAGs) with higher content of $\mathrm{P}$, wherein $\mathrm{P}$ was at the $s n-1$ (or 3) position, had higher melting points, crystallization temperatures, and packing densities of fat crystals compared to those with a lower content of $\mathrm{P}$, and with $\mathrm{P}$ at the $s n-2$ position. The in vitro digestion degree calculated as released fatty acid (FA) (\%) at 30, 60, and 120 min was in the following order: OPOrich > PPO-rich > POP-rich lipids. At $120 \mathrm{~min}$, in vitro digestion of the OPO-rich lipid released $92.6 \%$ of fatty acids, resulting in the highest digestibility, while $89.7 \%$ and $87.2 \%$ of fatty acids were released from the OPO-rich and PPO-rich lipids, respectively. Over the digestion period, the TAG and monoacylglycerol (MAG) contents decreased, while the diacylglycerol (DAG) content initially increased and then decreased, and the 1,2-DAG content exceeded the 1,3-DAG content. Therefore, the content and stereospecific position of $\mathrm{P}$ attached to a specific TAG affected the physicochemical and in vitro digestion characteristics of the lipids.
\end{abstract}

Keywords: in vitro digestion; palmitic acid; triacylglycerol; physicochemical property

\section{Introduction}

Triacylglycerol (TAG) is a lipid class consisting of one glycerol molecule linked to three fatty acids (FAs) via ester bonds. The type and regiospecific position of FAs incorporated into glycerol molecules affect the physicochemical and digestion characteristics of TAGs, such as the TAG profile, solid fat content, polymorphism, crystal morphology, melting point, and melting and crystallization temperatures [1]. Palmitic acid (P) is a major FA in palm oil, palm stearin, cocoa butter, and lard, and 1,2-dipalmitoyl-3-oleoylglycerol (PPO), a major P-containing TAG, was found in these lipids as 31.61\%, 15.23\%, 18.08\%, and $10.63 \%$, respectively [2]. Notably, 1-oleoyl-2-palmitoyl-3-linoleoylglycerol (OPL 28.08\%) and 1,3-dioleoyl-2-palmitoylglycerol (OPO 19.5\%) are the major TAGs found in breast milk [3]. Differential scanning calorimetry (DSC) has shown that the melting peaks of 1,3dipalmitoyl-2-oleoylglycerol (POP) and OPO are 36.5 and $21.9^{\circ} \mathrm{C}$, respectively [4,5]. Crystal morphology of OPO is characterized based on the evenness and density distribution of crystals in a small Maltese cross [6]. Notably, 1,2-dipalmitoyl-3-stearoylglycerol (PPS) and 1,3-dipalmitoyl-2-stearoylglycerol (PSP) are found in the Maltese cross form at $-25{ }^{\circ} \mathrm{C}$ [7]. TAGs produced using higher $\mathrm{P}$ and lower stearic acid (S) contents generally contain more $\beta^{\prime}$ form than $\beta$-form crystals [8].

TAGs have different digestion, absorption, and bioavailability rates depending on the type of FAs (unsaturation and carbon length) and the positions ( $s n-1,3$ or $s n-2)$ of the incorporation of FAs [9]. After ingestion, lipids are emulsified by bile acids and the FAs in the $s n-1,3$ position are hydrolyzed by pancreatic lipases, followed by absorption of 
2-monoacylglycerols (MAGs) and free fatty acids (FFAs) in enterocytes $[9,10]$. Long-chain saturated FAs (14 20 carbons in chain length), such as $\mathrm{P}$ and $\mathrm{S}$, in the $s n-1,3$ position of TAGs can be excreted as a form of insoluble FA soap after being hydrolyzed and bound with calcium or magnesium ions [9,10]. Among FAs, short-chain FAs (4 6 carbons in chain length) are most rapidly broken down by pancreatic lipases, followed by longchain/unsaturated FAs and saturated FAs [9]. Based on the apparent digestibility of individual FAs following the administration of soybean oil to mice, the digestibility of $\mathrm{P}$ $(88.43 \%)$ was higher than that of $\mathrm{S}(85.87 \%)$ in saturated FAs $(p<0.05)$, while the digestibility of linolenic acid $(96.2 \%)$ was the highest in unsaturated FAs, followed by those of linoleic acid $(93.63 \%)$ and oleic acid $(91.53 \%)(p<0.05)$ [11]. The in vivo absorption rates of the OPO and OOP diets in rats have been reported to be $80 \%$ and $67 \%$, respectively, and as an individual FA, the absorption rates of $\mathrm{P}$ in the administrated $\mathrm{OPO}$ and OOP are $80 \%$ and $63 \%$, respectively [12]. However, the results available on the importance of FA position on TAG digestion are still limited.

Tailored TAGs with $P$ at specific locations ( $s n-1,3$ or $s n-2)$ were synthesized by solvent fractionation or enzyme-catalyzed interesterification. For example, PPP-rich and POPrich lipids were synthesized from palm stearin by acetone-fractionation $[13,14]$, OPO (39.2\%) was synthesized with PPP-rich lipid, oleic acid, and linoleic acids by enzymecatalyzed interesterification [15]; cocoa butter replacer (PPP, POO/OPO, POP/PPO) was produced with coconut oil and palm stearin by enzyme-catalyzed reaction [16]; and OPO was synthesized with tripalmitin (PPP) and oleic acid by lipase-catalyzed acidolysis [17]. Most studies have focused on analyzing the physicochemical properties of TAGs that differ in the regiospecific positions of certain FAs [13-17]. Previous studies on lipid digestibility have measured and compared the relative digestion rates of edible oils (soybean oil, algae oil, DAG-rich algae oil) [18] and symmetrical or non-symmetrical TAGs based on the levels of hydrolyzed FFAs using the in vitro digestion method [19] or compared in vivo digestion rates of specific edible oils using animal models [11]. However, studies comparing the digestion characteristics of lipids containing TAGs with different types of FAs (such as P, O, or S) and the incorporated positions of the FAs are still limited.

To study lipid digestion, two in vitro digestion models are conveniently used. A $\mathrm{pH}$ stat-based model provides time-dependent kinetics of lipid lipolysis during a short period of digestion, and is useful as a rapid screening tool for assessing lipid digestibility; however, this model is a single-step model that simplifies the human digestive process by matching the chemical composition and $\mathrm{pH}$ of digestive condition in the small intestine only. On the other hand, the in vitro multi-step digestion model is designed to simulate the complex digestive process of the entire human gastrointestinal tract of the mouth, stomach, small intestine, and colon with a specifically composed digestive fluid (i.e., $\mathrm{pH}$, mineral composition, enzymes) [20]. Since the multiple-step digestion model proceeds the entire digestibility step by step, it can provide the status of lipid hydrolysis at specific points of lipid digestion, and studies can investigate the behavior of lipid digestion by measuring the composition of fatty acids and acylglycerols and their contents.

Up to date, most in vitro multi-step digestion models for lipids have been performed with pancreatic lipase in the small intestine, excluding the gastric lipase in the gastric phase. Sams et al. [21] noted that out of 340 articles published from 1967 to 2015, 94.9\% of the total in vitro models did not include gastric lipase since the lipase activity is markedly lower in the gastric phase than in the duodenal tract, and the lipolysis of gastric lipase is partial because of the lower secretion and variation in $\mathrm{pH}$ [22]. However, lipid digestion starts in the stomach with gastric lipase on TAGs, and gastric lipolysis contributes to the overall lipid digestion by triggering the subsequent action of pancreatic lipase on lipids. Therefore, recently, the amended and improved in vitro gastrointestinal digestion method (INFOGEST 2.0) included the use of gastric lipase in the gastric phase [23]. There are several commercial gastric lipases, such as rabbit gastric lipase and human gastric lipase encoded by the LIPF gene, but the high cost of these lipases can be a limiting factor for performing the in vitro gastrointestinal digestion model. 
In this study, four lipids were synthesized to assess the physicochemical and digestion characteristics of TAGs varying in the regiospecific position of palmitic acid. PPP-rich and POP-rich lipids were obtained via acetone fractionation of palm stearin, while PPO-rich and OPO-rich lipids were synthesized via lipase-catalyzed acidolysis. The physicochemical properties of the PPP-rich, POP-rich, PPO-rich, and OPO-rich lipids were compared by analyzing the compositions of acylglycerol, TAGs, and FAs; melting and crystallization properties; and crystal morphologies. Additionally, the digestion characteristics of the POP-rich, PPO-rich, and OPO-rich lipids were assessed by measuring their FA hydrolysis rates using an in vitro multi-step digestion model and by analyzing the changes in the acylglycerol and TAG compositions of the hydrolyzed lipids over digestion time.

\section{Results and Discussion}

\subsection{Acylglycerol Composition}

The acylglycerol compositions of the four lipids with different regiospecific positions of palmitic acid analyzed by ${ }^{1} \mathrm{H}-\mathrm{NMR}$, and the composition are presented with mmol\% using a tetramethylsilane (TMS) as a reference in Table 1. Acetone fractionation of palm stearin consisting of TAG $(96.9 \mathrm{mmol} \%)$ and DAG $(3.1 \mathrm{mmol} \%)$ at $28^{\circ} \mathrm{C}$ produced PPP-rich lipid, which was in the solid phase and consisted entirely of TAG (100 $\mathrm{mmol} \%)$, and POPrich lipid, which was in the liquid phase and consisted of $93.4 \mathrm{mmol} \% \mathrm{TAG}, 6.3 \mathrm{mmol} \%$ $\mathrm{DAG}$, and $0.3 \mathrm{mmol} \% \mathrm{MAG}$. The presence of DAG and MAG in the POP-rich lipid may be attributed to their relatively low melting points, which contributed to the transition into the liquid phase during the fractionation process (Figure 1). The PPO-rich and OPO-rich lipids consisted of 99.1 99.3 mmol\% TAG, $0.7 \mathrm{mmol} \%$ DAG, and 0.1 0.2 mmol\% MAG.

Table 1. Acylglyerol composition of the lipids.

\begin{tabular}{|c|c|c|c|c|c|}
\hline Acylglycerol (mmol\%) & Palm Stearin & PPP-Rich Lipid & POP-Rich Lipid & PPO-Rich Lipid & OPO-Rich Lipid \\
\hline Triacylglycerol (TAG) & $96.9 \pm 0.0^{\mathrm{d}(1)}$ & $100.0 \pm 0.0^{\mathrm{a}}$ & $93.4 \pm 0.0^{\mathrm{e}}$ & $99.1 \pm 0.0^{c}$ & $99.3 \pm 0.0^{b}$ \\
\hline Diacylglycerol (DAG) & $3.1 \pm 0.0^{b}$ & $0.0 \pm 0.0^{\mathrm{d}}$ & $6.3 \pm 0.1^{\mathrm{a}}$ & $0.7 \pm 0.0^{c}$ & $0.7 \pm 0.0^{c}$ \\
\hline $1,3-\mathrm{DAG}$ & $1.3 \pm 0.0^{b}$ & $0.0 \pm 0.0^{\mathrm{d}}$ & $3.1 \pm 0.1^{\mathrm{a}}$ & $0.4 \pm 0.0^{\mathrm{c}}$ & $0.3 \pm 0.0^{\mathrm{c}}$ \\
\hline 1,2-DAG & $1.9 \pm 0.0^{b}$ & $0.0 \pm 0.0^{\mathrm{d}}$ & $3.3 \pm 0.1^{\mathrm{a}}$ & $0.3 \pm 0.0^{\mathrm{c}}$ & $0.3 \pm 0.0^{c}$ \\
\hline Monoacylglycerol (MAG) & $-(2)$ & - & $0.3 \pm 0.0^{\mathrm{a}}$ & $0.2 \pm 0.0^{b}$ & $0.1 \pm 0.0^{\mathrm{c}}$ \\
\hline $1-\mathrm{MAG}$ & - & - & $0.1 \pm 0.0^{b}$ & $0.2 \pm 0.0^{\mathrm{a}}$ & $0.0 \pm 0.0^{\mathrm{c}}$ \\
\hline 2-MAG & - & - & $0.1 \pm 0.0^{\mathrm{a}}$ & $0.0 \pm 0.0^{b}$ & $0.1 \pm 0.0^{b}$ \\
\hline
\end{tabular}

(1) a-e Means in the same row with different letters are significantly different according to Duncan's multiple range test at $p<0.05$. Mean \pm $\mathrm{SD}(n=2){ }^{(2)}$ : Not detected.

\subsection{Fatty Acids Composition}

The major FAs in palm stearin were P (C16:0, 63.4\%), O (C18:1, 24.9\%), L (C18.2, 5.1\%), and $\mathrm{S}(\mathrm{C} 18: 0,4.8 \%)$, and the main FAs at the $s n-2$ position were $\mathrm{P}(45.6 \%), \mathrm{O}(42.5 \%)$, and $\mathrm{L}$ (9.1\%) (Tables 2 and 3). The major FAs in the four lipids obtained were $\mathrm{P}(30.2 \sim 79.4 \%), \mathrm{S}$ (2.5 5.0\%), O (11.6 60.9\%), and L (2.12 8.19\%) (Table 2). The P contents in the lipids were in the following order: PPP-rich $(79.4 \%)>$ PPO-rich $(46.9 \%)>$ POP-rich $(46.5 \%)>$ OPO-rich lipids $(30.2 \%)(p<0.05)$. The $\mathrm{O}$ contents in the lipids were in the following order: OPO-rich $(60.9 \%)>$ PPO-rich $(45.3 \%)>$ POP-rich $(38.9 \%)>$ PPP-rich lipids $(11.6 \%)(p<0.05)$. The $S$ and $\mathrm{L}$ contents were significantly higher in the PPP-rich and POP-rich lipids, respectively $(p<0.05)$. 


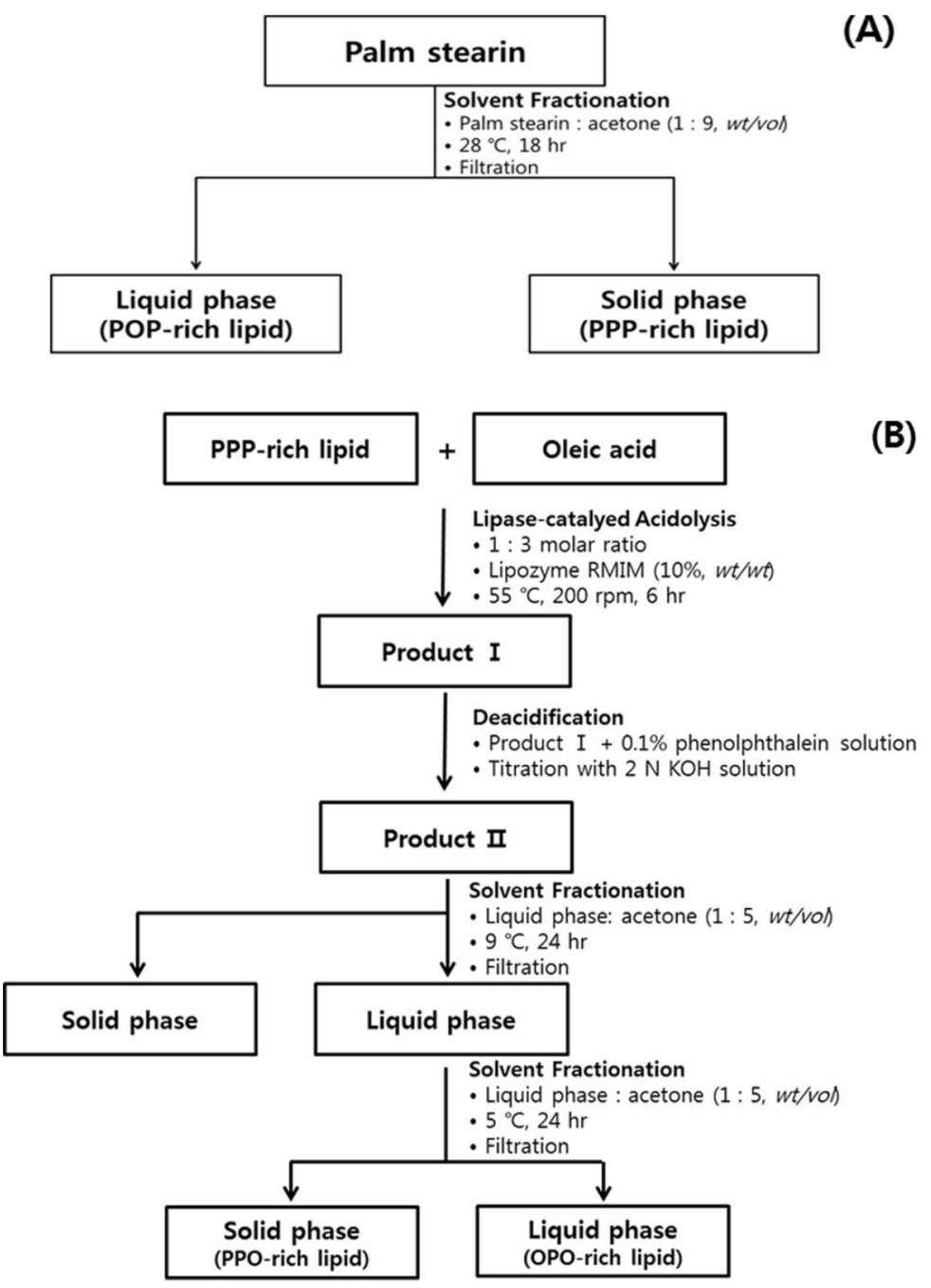

Figure 1. Production scheme of PPP-rich and POP-rich lipids (A), PPO-rich, and OPO-rich lipids (B).

Table 2. Total fatty acids composition and melting points of the lipids.

\begin{tabular}{|c|c|c|c|c|c|}
\hline $\begin{array}{c}\text { Fatty Acid } \\
\text { (\% of Total Fatty Acids) }\end{array}$ & Palm Stearin & PPP-Rich Lipid & POP-Rich Lipid & PPO-Rich Lipid & OPO-Rich Lipid \\
\hline C14:0 & $1.1 \pm 0.0$ & $1.3 \pm 0.0$ & $0.9 \pm 0.0$ & $0.5 \pm 0.0$ & $0.7 \pm 0.0$ \\
\hline C16:0 & $63.4 \pm 0.2^{b(1)}$ & $79.4 \pm 0.0^{\mathrm{a}}$ & $46.5 \pm 0.0^{\mathrm{d}}$ & $46.9 \pm 0.0^{c}$ & $30.2 \pm 0.1^{\mathrm{e}}$ \\
\hline C18:0 & $4.8 \pm 0.0^{\mathrm{b}}$ & $5.0 \pm 0.0^{\mathrm{a}}$ & $4.5 \pm 0.0^{c}$ & $3.7 \pm 0.0^{\mathrm{d}}$ & $2.5 \pm 0.1^{\mathrm{e}}$ \\
\hline C18:1t & $0.1 \pm 0.0$ & - (2) & $0.1 \pm 0.0$ & $0.7 \pm 0.0$ & $1.0 \pm 0.0$ \\
\hline C18:1n-9c & $24.9 \pm 0.2^{\mathrm{d}}$ & $11.6 \pm 0.0^{\mathrm{e}}$ & $38.9 \pm 0.0^{c}$ & $45.3 \pm 0.0^{b}$ & $60.9 \pm 0.2^{\mathrm{a}}$ \\
\hline C18:1n-7c & $0.4 \pm 0.0$ & $0.2 \pm 0.0$ & $0.6 \pm 0.0$ & - & - \\
\hline$C 18: 2 n-6 c$ & $5.1 \pm 0.0^{b}$ & $2.1 \pm 0.0^{\mathrm{e}}$ & $8.2 \pm 0.0^{\mathrm{a}}$ & $2.8 \pm 0.0^{\mathrm{d}}$ & $4.6 \pm 0.1^{\mathrm{c}}$ \\
\hline C20:0 & $0.3 \pm 0.0$ & $0.3 \pm 0.0$ & $0.3 \pm 0.0$ & $0.2 \pm 0.0$ & $0.2 \pm 0.0$ \\
\hline SFA $^{(3)}$ & $69.6 \pm 0.2^{b}$ & $86.0 \pm 0.0^{\mathrm{a}}$ & $52.2 \pm 0.0^{\mathrm{c}}$ & $51.2 \pm 0.0^{\mathrm{d}}$ & $33.5 \pm 0.2^{\mathrm{e}}$ \\
\hline USFA $^{(3)}$ & $30.4 \pm 0.2^{\mathrm{d}}$ & $14.0 \pm 0.0^{\mathrm{e}}$ & $47.8 \pm 0.0^{\mathrm{c}}$ & $48.8 \pm 0.0^{b}$ & $66.5 \pm 0.2^{\mathrm{a}}$ \\
\hline MUFA $^{(3)}$ & $25.3 \pm 0.2^{\mathrm{d}}$ & $11.9 \pm 0.0^{\mathrm{e}}$ & $39.6 \pm 0.0^{c}$ & $46.0 \pm 0.0^{b}$ & $61.9 \pm 0.3^{a}$ \\
\hline Slip melting point $\left({ }^{\circ} \mathrm{C}\right)$ & $55.6 \pm 0.4^{b}$ & $59.5 \pm 0.7^{\mathrm{a}}$ & $27.3 \pm 0.4^{\mathrm{c}}$ & $26.5 \pm 0.0^{c}$ & $15.0 \pm 0.0^{\mathrm{d}}$ \\
\hline Complete melting point $\left({ }^{\circ} \mathrm{C}\right)$ & $57.0 \pm 0.0^{b}$ & $61.5 \pm 0.0^{\mathrm{a}}$ & $29.5 \pm 0.7^{c}$ & $27.5 \pm 0.0^{\mathrm{d}}$ & $18.5 \pm 0.7^{\mathrm{e}}$ \\
\hline
\end{tabular}

(1) a-e Means in the same row with different letters are significantly different at $p<0.05$, as determined by Duncan's multiple range test.

Mean \pm SD $(n=2) .{ }^{(2)}$ : Not detected. ${ }^{(3)}$ SFA, saturated fatty acid; USFA, unsaturated fatty acid; MUFA, monounsaturated fatty acid. 
Table 3. The $s n-2$ and $s n-1,3$ positional fatty acid compositions of the lipids.

\begin{tabular}{|c|c|c|c|c|c|}
\hline $\begin{array}{c}\text { Fatty Acid } \\
\text { (\% of Total Fatty Acids) }\end{array}$ & Palm Stearin & PPP-Rich Lipid & POP-Rich Lipid & PPO-Rich Lipid & OPO-Rich Lipid \\
\hline \multicolumn{6}{|l|}{ sn-2 position } \\
\hline $\mathrm{C} 16: 0$ & $45.6 \pm 1.6^{\mathrm{d}(1)}$ & $73.4 \pm 0.3^{b}$ & $14.3 \pm 0.1^{\mathrm{e}}$ & $81.2 \pm 2.1^{\mathrm{a}}$ & $60.3 \pm 0.7^{c}$ \\
\hline C18:0 & $2.8 \pm 0.8^{\mathrm{ab}}$ & $4.3 \pm 1.5^{\mathrm{a}}$ & $1.3 \pm 0.0^{b}$ & $2.2 \pm 0.3^{b}$ & $3.1 \pm 0.0^{\mathrm{ab}}$ \\
\hline C18:1n-9c & $42.5 \pm 1.8^{b}$ & $19.9 \pm 0.2^{\mathrm{d}}$ & $67.9 \pm 0.1^{\mathrm{a}}$ & $13.0 \pm 1.0^{\mathrm{e}}$ & $31.8 \pm 0.1^{\mathrm{c}}$ \\
\hline$C 18: 2 n-6 c$ & $9.1 \pm 0.6^{b}$ & $2.3 \pm 0.9^{\mathrm{d}}$ & $16.5 \pm 0.0^{a}$ & $3.6 \pm 0.8^{\mathrm{cd}}$ & $4.8 \pm 0.8^{c}$ \\
\hline SFA ${ }^{(2)}$ & $48.4 \pm 2.4^{\mathrm{d}}$ & $77.8 \pm 1.2^{b}$ & $15.7 \pm 0.1^{\mathrm{e}}$ & $83.4 \pm 1.8^{a}$ & $63.4 \pm 0.7^{c}$ \\
\hline USFA $^{(2)}$ & $51.6 \pm 2.4^{b}$ & $22.2 \pm 1.2^{\mathrm{d}}$ & $84.3 \pm 0.1^{\mathrm{a}}$ & $16.6 \pm 1.8^{\mathrm{e}}$ & $36.6 \pm 0.7^{c}$ \\
\hline MUFA $^{(2)}$ & $42.5 \pm 1.8^{\mathrm{b}}$ & $19.9 \pm 0.2^{\mathrm{d}}$ & $67.9 \pm 0.1^{\mathrm{a}}$ & $13.0 \pm 1.0^{\mathrm{e}}$ & $31.8 \pm 0.1^{\mathrm{c}}$ \\
\hline \multicolumn{6}{|l|}{$s n-1,3$ position } \\
\hline C14:0 & $1.6 \pm 0.0$ & $1.9 \pm 0.0$ & $1.3 \pm 0.0$ & $0.8 \pm 0.0$ & $1.0 \pm 0.0$ \\
\hline C16:0 & $72.3 \pm 0.4^{b}$ & $82.3 \pm 0.2^{\mathrm{a}}$ & $62.5 \pm 0.0^{\mathrm{c}}$ & $29.7 \pm 1.1^{\mathrm{d}}$ & $15.2 \pm 0.6^{\mathrm{e}}$ \\
\hline C18:0 & $5.8 \pm 0.5^{\mathrm{a}}$ & $5.4 \pm 0.7^{\mathrm{ab}}$ & $6.1 \pm 0.0^{\mathrm{a}}$ & $4.5 \pm 0.2^{b}$ & $2.2 \pm 0.1^{\mathrm{c}}$ \\
\hline C18:1t & $0.1 \pm 0.0$ & $-(3)$ & $0.1 \pm 0.0$ & $1.1 \pm 0.0$ & $1.5 \pm 0.1$ \\
\hline C18:1n-9c & $16.0 \pm 0.6^{\mathrm{d}}$ & $7.5 \pm 0.1^{\mathrm{e}}$ & $24.3 \pm 0.0^{c}$ & $61.4 \pm 0.5^{b}$ & $75.4 \pm 0.3^{a}$ \\
\hline $\mathrm{C} 18: 1 \mathrm{n}-7 \mathrm{c}$ & $0.6 \pm 0.0$ & $0.3 \pm 0.0$ & $1.0 \pm 0.0$ & - & - \\
\hline$C 18: 2 n-6 c$ & $3.0 \pm 0.3^{b}$ & $2.0 \pm 0.5^{c}$ & $4.1 \pm 0.0^{\mathrm{a}}$ & $2.3 \pm 0.4^{b c}$ & $4.5 \pm 0.3^{\mathrm{a}}$ \\
\hline C20:0 & $0.5 \pm 0.0$ & $0.5 \pm 0.0$ & $0.5 \pm 0.0$ & $0.2 \pm 0.0$ & $0.2 \pm 0.0$ \\
\hline SFA ${ }^{(2)}$ & $80.2 \pm 0.9^{b}$ & $90.1 \pm 0.6^{a}$ & $70.4 \pm 0.0^{c}$ & $35.2 \pm 0.9^{d}$ & $18.6 \pm 0.7^{\mathrm{e}}$ \\
\hline USFA $^{(2)}$ & $19.8 \pm 0.9^{\mathrm{d}}$ & $9.9 \pm 0.6^{\mathrm{e}}$ & $29.6 \pm 0.0^{c}$ & $64.8 \pm 0.9^{b}$ & $81.4 \pm 0.7^{\mathrm{a}}$ \\
\hline MUFA ${ }^{(2)}$ & $16.8 \pm 0.6^{\mathrm{d}}$ & $7.8 \pm 0.1^{\mathrm{e}}$ & $25.4 \pm 0.0^{\mathrm{c}}$ & $62.5 \pm 0.5^{\mathrm{b}}$ & $76.9 \pm 0.3^{a}$ \\
\hline
\end{tabular}

(1) a-e Means in the same row with different letters are significantly different at $p<0.05$, as determined by Duncan's multiple range test. Mean \pm SD. $(n=2) .{ }^{(2)}$ : SFA, saturated fatty acid; USFA, unsaturated fatty acid; MUFA, monounsaturated fatty acid. ${ }^{(3)}$ : Not detected.

The P contents at the $s n-2$ position in the lipids were as follows: PPO-rich $(81.2 \%)>$ PPP-rich $(73.4 \%)>$ OPO-rich $(60.3 \%)>$ POP-rich lipids $(14.3 \%)(p<0.05)$. The O contents at the $s n-2$ position in the lipids were as follows: POP-rich $(67.86 \%)>$ OPO-rich $(31.80 \%)$ $>$ PPP-rich $(19.91 \%)>$ PPO-rich lipids $(14.3 \%)(p<0.05)$ (Table 3). The P contents at the $s n-1,3$ position were as follows: PPP-rich $(82.3 \%)>$ POP-rich $(62.5 \%)>$ PPO-rich $(29.7 \%)>$ OPO-rich lipids $(15.2 \%)(p<0.05)$. The $\mathrm{O}$ contents at the $s n-1,3$ position were significantly higher in the following order: OPO-rich $(75.4 \%)>$ PPO-rich $(61.4 \%)>$ POP-rich $(24.3 \%)>$ PPP-rich lipids $(7.5 \%)(p<0.05)$. The four lipids synthesized in the present study contained 85.2-92.2\% of $\mathrm{P}$ and $\mathrm{O}$, and the incorporated positions were distinctly different on the glycerol backbones of TAGs.

\subsection{Triacylglycerol Composition}

TAGs in the lipids were separated based on the number of double bonds and their geometrical configurations using silver ion-HPLC, and designated as saturated FA (Sa), monounsaturated FA(Mo), and diunsaturated FA(D) in the HPLC chromatogram (Figure 2).

According to the results of the FA analysis (Tables 2 and 3), Sa, Mo, and D were composed mainly of $\mathrm{P}, \mathrm{O}$, and L. Notably, Sa contained a small amount of $\mathrm{S}$. Thus, the major TAGs were SaSaSa (PPP, PSP, SPS, PPS, SSP, SSS; main TAG, PPP), SaMoSa (POP, POS, SOS; main TAG, POP), SaSaMo (PPO, SSO, PSO, SPO; main TAG, PPO), MoSaMo (OPO, OSO; main TAG, OPO), and SaSaD/SaDSa (PPL, SSL, PSL, SPL/POO, SOO; main TAG, POO). The minor TAGs were SaDSa (PLP, PLS, SLS; main TAG, PLP), SaDMo/SaMoD (PLO, SLO/POL, SOL; main TAG, PLO/POL), and MoMoMo (OOO) (Table 4). 


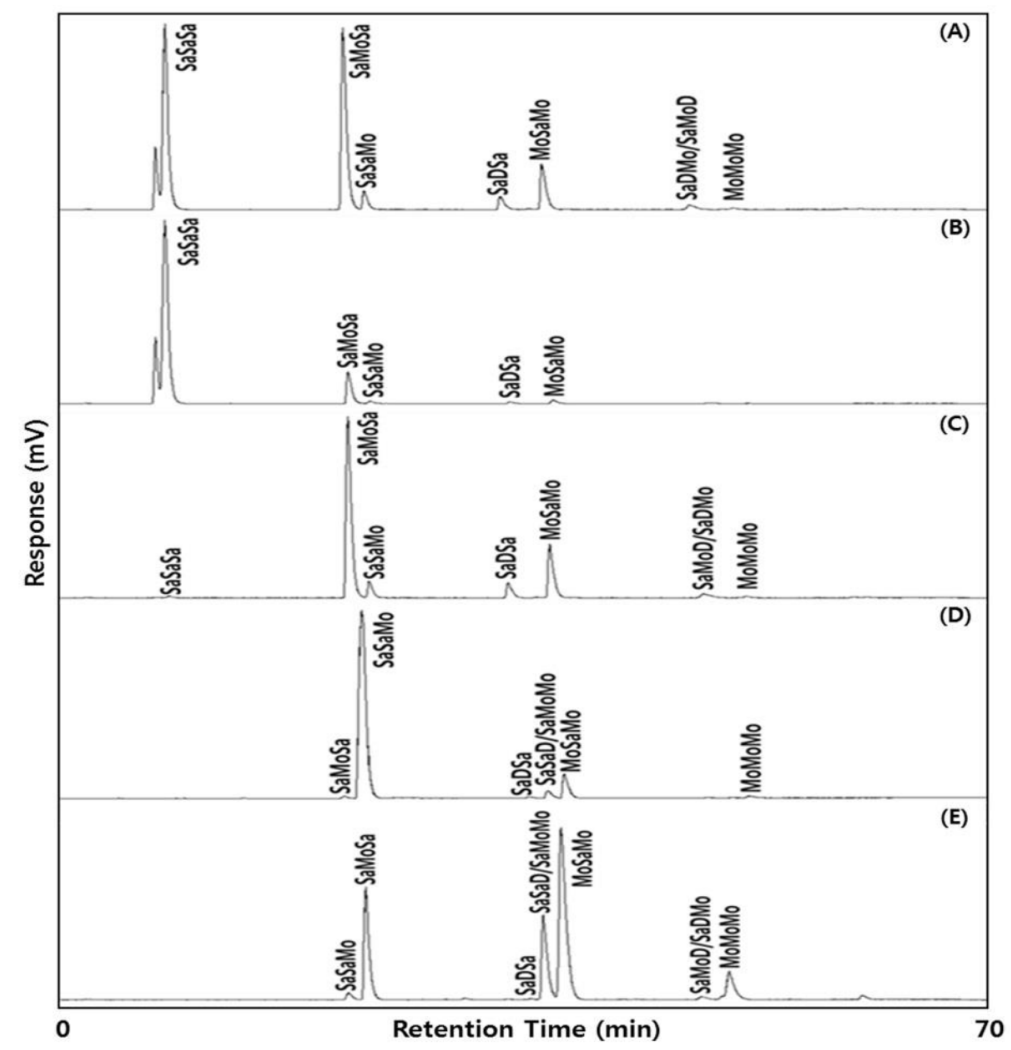

Figure 2. Ag-HPLC chromatograms of the lipids, (A) Palm stearin; (B) PPP-rich lipid; (C) POP-rich lipid; (D) PPO-rich lipid; (E) OPO-rich lipid. The abbreviations are presented in the results and discussion.

Table 4. Triacylglycerol compositions of lipids.

\begin{tabular}{|c|c|c|c|c|c|}
\hline $\begin{array}{c}\text { Triacylglycerol }^{(1)} \\
\text { (\% of Total Triayclglyerol) }\end{array}$ & Palm Stearin & PPP-Rich Lipid & POP-Rich Lipid & PPO-Rich Lipid & OPO-Rich Lipid \\
\hline SaSaSa (PPP) & $38.0 \pm 0.2^{b(2)}$ & $81.2 \pm 1.1^{\mathrm{a}}$ & $0.6 \pm 0.0^{\mathrm{c}}$ & - (3) & - \\
\hline SaMoSa (POP) & $42.4 \pm 0.3^{b}$ & $15.1 \pm 0.8^{\mathrm{c}}$ & $64.4 \pm 1.4^{\mathrm{a}}$ & $0.7 \pm 0.1^{\mathrm{d}}$ & $1.6 \pm 0.1^{\mathrm{d}}$ \\
\hline SaSaMo (PPO) & $3.8 \pm 0.2^{c}$ & $1.2 \pm 0.1^{\mathrm{d}}$ & $5.5 \pm 0.0^{c}$ & $86.5 \pm 0.2^{\mathrm{a}}$ & $22.0 \pm 2.0^{b}$ \\
\hline SaDSa (PLP) & $3.2 \pm 0.1^{b}$ & $0.8 \pm 0.1^{c}$ & $5.8 \pm 0.2^{\mathrm{a}}$ & $0.5 \pm 0.0^{\mathrm{d}}$ & $0.2 \pm 0.0^{\mathrm{e}}$ \\
\hline $\begin{array}{c}\text { SaSaD/SaMoMo } \\
\text { (PPL/POO) }\end{array}$ & - & - & - & $2.9 \pm 0.1$ & $18.6 \pm 0.4 *(4)$ \\
\hline MoSaMo (OPO) & $10.8 \pm 0.3^{c}$ & $1.9 \pm 0.1^{\mathrm{d}}$ & $20.3 \pm 0.9^{b}$ & $8.7 \pm 0.1^{\mathrm{c}}$ & $50.2 \pm 2.7^{\mathrm{a}}$ \\
\hline $\begin{array}{l}\text { SaDMo/SaMoD } \\
\text { (PLO/POL) }\end{array}$ & $1.5 \pm 0.1^{b}$ & - & $2.9 \pm 0.4^{\mathrm{a}}$ & - & $0.7 \pm 0.1^{\mathrm{c}}$ \\
\hline MoMoMo (OOO) & $0.3 \pm 0.0^{\mathrm{d}}$ & - & $0.6 \pm 0.0^{\mathrm{c}}$ & $0.8 \pm 0.1^{b}$ & $6.8 \pm 0.1^{\mathrm{a}}$ \\
\hline
\end{tabular}

(1) The abbreviations were presented in the results and discussion, and abbreviations in parentheses refer to the major TAGs. (2) a-e: Means in the same row with different letters are significantly different at $p<0.05$, as determined by Duncan's multiple range test. Mean \pm SD. $(n=2) .{ }^{(3)}$ : Not detected. ${ }^{(4)} *$ : Differences between PPO-rich lipid and OPO-rich lipid are significantly different by Student's $t$-test $(p<0.05)$.

The major TAGs of palm stearin were PPP (38.0\%), POP (42.4\%), PPO (3.8\%), PLP $(3.2 \%)$, and OPO $(10.8 \%)$. The major TAGs of the PPP-rich lipids were PPP $(81.2 \%)$ and POP (15.1\%), and those of the POP-rich lipids were POP (64.4\%) and OPO (20.3\%). The major TAGs of PPO-rich lipids were PPO (86.5\%) and OPO (8.7\%). The major TAGs of the OPO-rich lipids were OPO (50.2\%), PPO (22.020\%), and PPL/POO (18.6\%), and a small amount of $\mathrm{OOO}(6.8 \%)$ also constituted OPO-rich lipids. Therefore, the four lipids synthesized mainly contained PPP, POP, PPO, and OPO, the contents of which varied. Wei et al. [17] produced a lipid consisting of $40.23 \%$ OPO by Lipozyme RMIM-catalyzed acidolysis, and Lee et al. [13] synthesized a lipid with $32.68 \%$ OPO from palm stearin and 
oleic acid using Lipozyme TLIM. The OPO content (50.2\%) of the OPO-rich lipid in the present study was 1.25-1.54 times higher than in the previous studies.

\subsection{Melting Points}

The slip melting point (SMP) and complete melting point (CMP) of palm stearin were 55.6 and $57.0^{\circ} \mathrm{C}$, respectively (Table 2). The SMPs of the four lipids were in the following order: PPP-rich $\left(59.5^{\circ} \mathrm{C}\right)>$ POP-rich $\left(27.3^{\circ} \mathrm{C}\right)$, PPO-rich $\left(26.5^{\circ} \mathrm{C}\right)>$ OPO-rich lipid $\left(15.0^{\circ} \mathrm{C}\right)$ $(p<0.05)$. The CMPs were in the following order: PPP-rich $\left(61.5^{\circ} \mathrm{C}\right)>$ POP-rich $\left(29.5^{\circ} \mathrm{C}\right)>$ PPO-rich $\left(27.5^{\circ} \mathrm{C}\right)>\mathrm{OPO}$-rich lipid $\left(18.5^{\circ} \mathrm{C}\right)(p<0.05)$. The MPs of lipids were influenced by their FA contents. The higher the SFA content, the higher the MP, and the higher the content of short-chain FA and USFA, the lower the MP [24]. Among the four lipids, the MP of PPP-rich lipid with the highest SFA content (86.0\%) and the lowest USFA content $(14.0 \%)$ was the highest, while that of the OPO-rich lipid with the lowest SFA content $(33.5 \%)$ and highest USFA content $(61.9 \%)$ was the lowest. The CMPs of POP-rich lipids were higher than those of PPO-rich lipids $(p<0.05)$ because although the SFA contents in POP-rich $(52.1 \%)$ and PPO-rich lipids $(51.2 \%)$ were similar, their major SFAs were $\mathrm{S}\left(\mathrm{MP}, 69.4^{\circ} \mathrm{C}\right)$ and $\mathrm{P}\left(\mathrm{MP}, 62.5 \sim 63.0^{\circ} \mathrm{C}\right)$, respectively, and the $\mathrm{S}$ content was 1.21 times higher in PPO-rich lipids than in POP-rich lipids $(p<0.05)$ [25-27]. The MPs of lipids were also affected by the locations of the incorporated FAs (sn-1,3 or sn-2) in the TAG structure. Motoyama [28] reported that the MPs of TAGs containing $\mathrm{P}, \mathrm{S}$, and $\mathrm{O}$ are higher for POP $\left(37^{\circ} \mathrm{C}\right)$ and SOS $\left(43^{\circ} \mathrm{C}\right)$ than for $\mathrm{PPO}\left(35^{\circ} \mathrm{C}\right)$ and $\mathrm{SSO}\left(41^{\circ} \mathrm{C}\right)$, respectively, and that the MP is increased when SFA is incorporated in the $s n-1,3$ position rather than the $s n-2$ position. Consistent with these reports, the MP of the POP-rich lipid was higher than that of the PPO-rich lipid due to the two-fold higher SFA content at the $s n-1,3$ position and a higher $\mathrm{S}$ content in the POP-rich lipid than in the PPO-rich lipid.

\subsection{Crystallization and Melting Properties}

The melting and crystallization characteristics analyzed by DSC are shown in Figure 3. In the crystallization curve (Figure $3 \mathrm{~A}$ ), palm stearin showed a large sharp crystallization peak at $27.25^{\circ} \mathrm{C}$ and a small peak at $0.31^{\circ} \mathrm{C}$. The crystallization onset temperatures were in the following order: PPP-rich > POP-rich > PPO-rich > OPO-rich lipids. The PPP-, PPO-, and OPO-rich lipids showed very distinct large crystallization peaks at 33.61, 8.29, and $-5.31{ }^{\circ} \mathrm{C}$, respectively. Thus, it appears that crystallization mostly occurs at these temperatures. The POP-rich lipid showed two crystallization peaks $\left(10.71\right.$ and $\left.0.82{ }^{\circ} \mathrm{C}\right)$ from $-19.08{ }^{\circ} \mathrm{C}$ to $12.62{ }^{\circ} \mathrm{C}$, indicating that crystallization occurred twice in this temperature range. The four lipids had different crystallization onset temperatures and crystallization peaks due to their different TAG compositions and contents. Gwie et al. [29] reported a large crystallization peak at $38.8{ }^{\circ} \mathrm{C}$ for PPP (purity $85 \%$ ), which is higher than the temperature at which a crystallization peak was observed $\left(33.61^{\circ} \mathrm{C}\right)$ for the PPP-rich lipid (SaSaSa, 81.2\%) in the present study. Even though the SaSaSa concentration is lower than the PPP concentration (85\%) [29], since SaSaSa in PPP-rich lipid was composed of a mixture of $\mathrm{P}$ (major) and $\mathrm{S}$ (minor), the crystallization peak of SaSaSa can be lower than that of PPP [29].

In the melting curve (Figure 3B), palm stearin showed a large melting peak at $51.74{ }^{\circ} \mathrm{C}$, and completely melted at $53.55^{\circ} \mathrm{C}$. PPP-rich and PPO-rich lipids had large melting peaks at 56.98 and $21.78{ }^{\circ} \mathrm{C}$, respectively, and melted completely at 59.02 and $26.29{ }^{\circ} \mathrm{C}$, respectively. Although POP-rich and OPO-rich lipids did not show large melting peaks, their melting ranges were $-30.92 \sim 32.49$ and $-26.29 \sim 16.03{ }^{\circ} \mathrm{C}$, and these lipids melted completely at 32.49 and $16.03{ }^{\circ} \mathrm{C}$, respectively. In the melting curves of palm stearin, PPP-rich, PPO-rich, and OPO-rich lipids, the DSC melting end points were in the range of SMP-CMP (Table 2), showing the consistency of the analyzed melting property between DSC and the capillary tube method (for measuring SMP and CMP). 

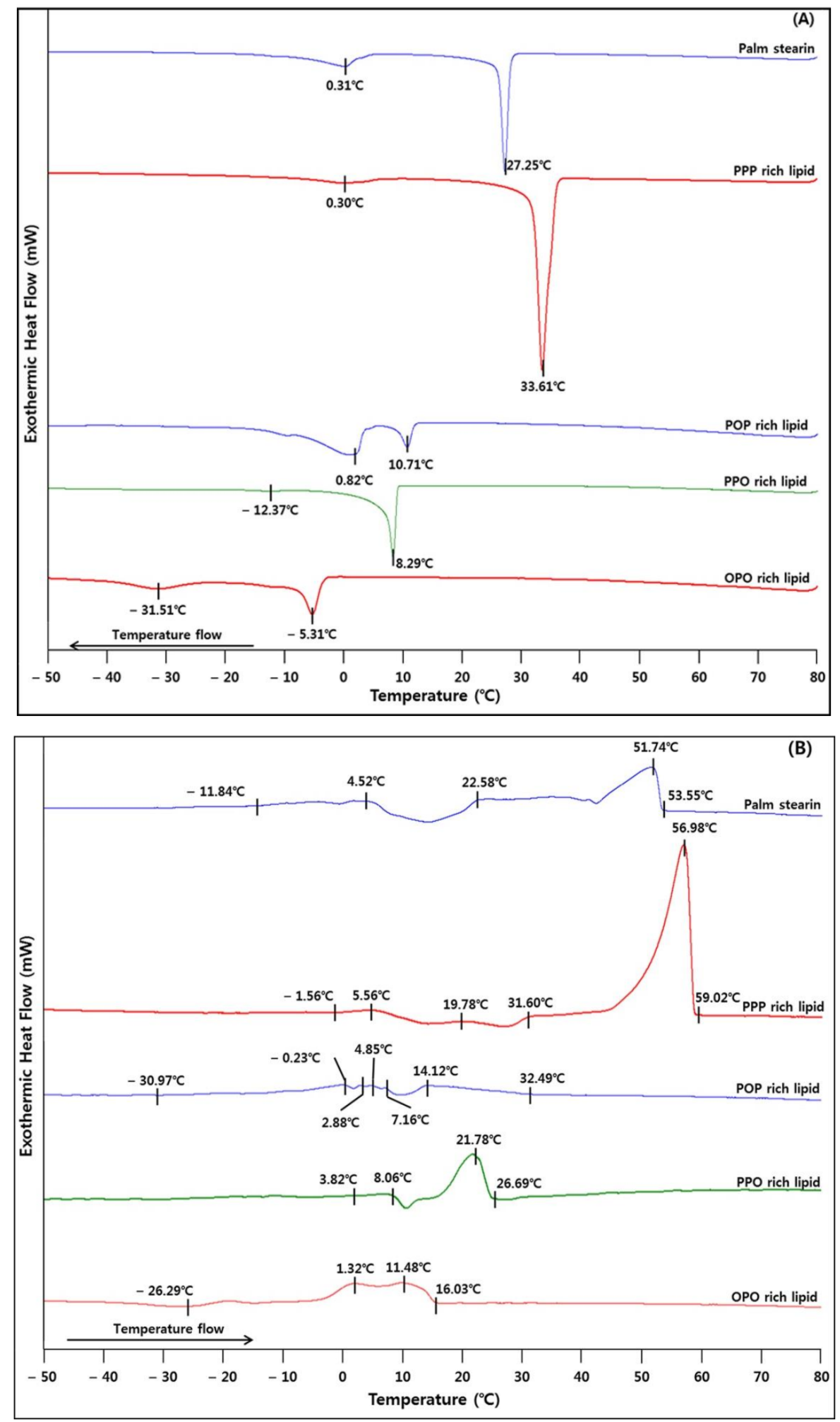

Figure 3. Differential scanning calorimetry crystallization (A) and melting (B) curves of the lipids.

\subsection{Crystal Morphology}

Figure 4 shows the distinctly different crystal morphologies of palm stearin and PPP-rich, POP-rich, PPO-rich, and OPO-rich lipids stored at $4{ }^{\circ} \mathrm{C}$ for $16 \mathrm{~h}$. Rod-like spherulitic crystals were observed for palm stearin, showing the similar crystal morphology in palm stearin of the study of Lee et al. [8]. The PPP-rich lipid with a high crystallization 
temperature had the largest crystals and a high packing density among all the lipids. The crystals in the POP-rich lipid were in the form of a small needle, the smallest in size, and highly packed. The PPO-rich lipid showed rod-like crystals that were larger and more tightly packed than the crystals in the POP-rich lipid. The OPO-rich lipid had small and large crystal aggregates in the shape of a spherical Maltese cross with low packing density. The OPO-rich lipid had a distinct crystallization peak at $-5.31{ }^{\circ} \mathrm{C}$, while it had a broad melting range of -5.44 to $16.03{ }^{\circ} \mathrm{C}$ with multiple melting peaks due to having a mixture of TAGs (Figure 3B), and melted completely at $18.5^{\circ} \mathrm{C}$ (Table 2). It seemed that the various TAGs present in OPO-rich lipid were simultaneously crystallized and melted at the storage temperature of $4{ }^{\circ} \mathrm{C}$ for $16 \mathrm{~h}$. During this process, crystal nucleation, growth, and agglomeration proceeded, leading to the formation of diverse crystal aggregates of clusters, in which the solid fat (white) was held in the liquid oil (black) (Figure 4E).
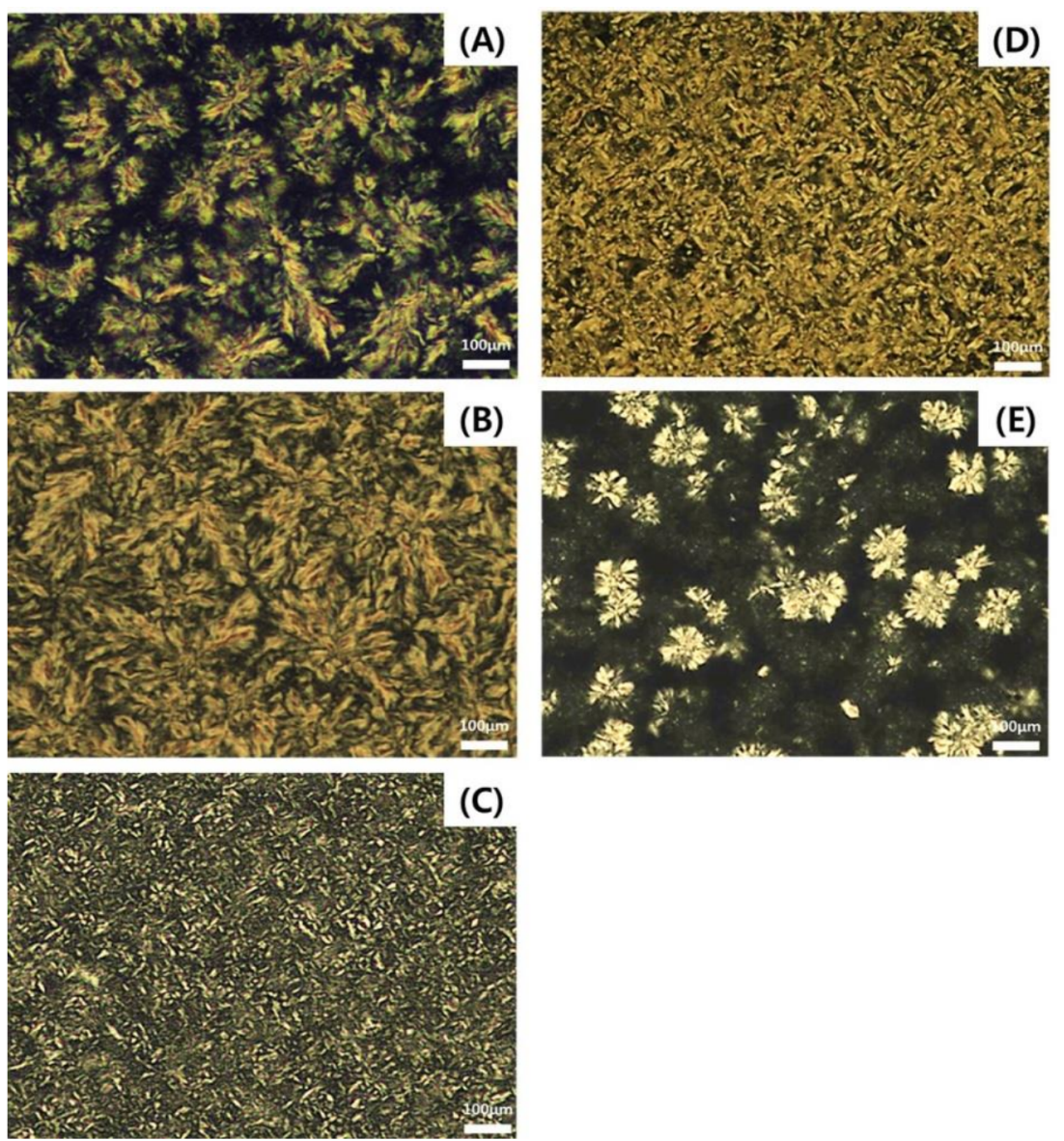

Figure 4. Polarized light micrographs of (A) palm stearin, (B) PPP-rich lipid, (C) POP-rich lipid, (D) PPO-rich lipid, and (E) OPO-rich lipid (stored at $4{ }^{\circ} \mathrm{C}$ for $16 \mathrm{~h}$ ). The scale bar represents $100 \mu \mathrm{m}$.

\subsection{Free Fatty Acids (FFAs) Released by the Hydrolyzed Lipids during In Vitro Multi-Step Digestion}

The in vitro digestion degrees of POP-rich, PPO-rich, and OPO-rich lipids were measured based on the levels of FFAs at 30,60, and 120 min of digestion using the in vitro multi-step model (Figure 5). The digestion degrees of all lipids increased with digestion time, and were in the following order: OPO-rich $>$ PPO-rich $>$ POP-rich lipids with a significance at each digestion time $(p<0.05)$. The FFAs released $(\%)$ of the OPO-rich lipid were 1.07 and 1.36 times higher at $30 \mathrm{~min}, 1.17$ and 1.20 times higher at $60 \mathrm{~min}$, and 1.15 and 1.27 times higher at 120 min than those of the PPO- and POP-rich lipids, respectively. 


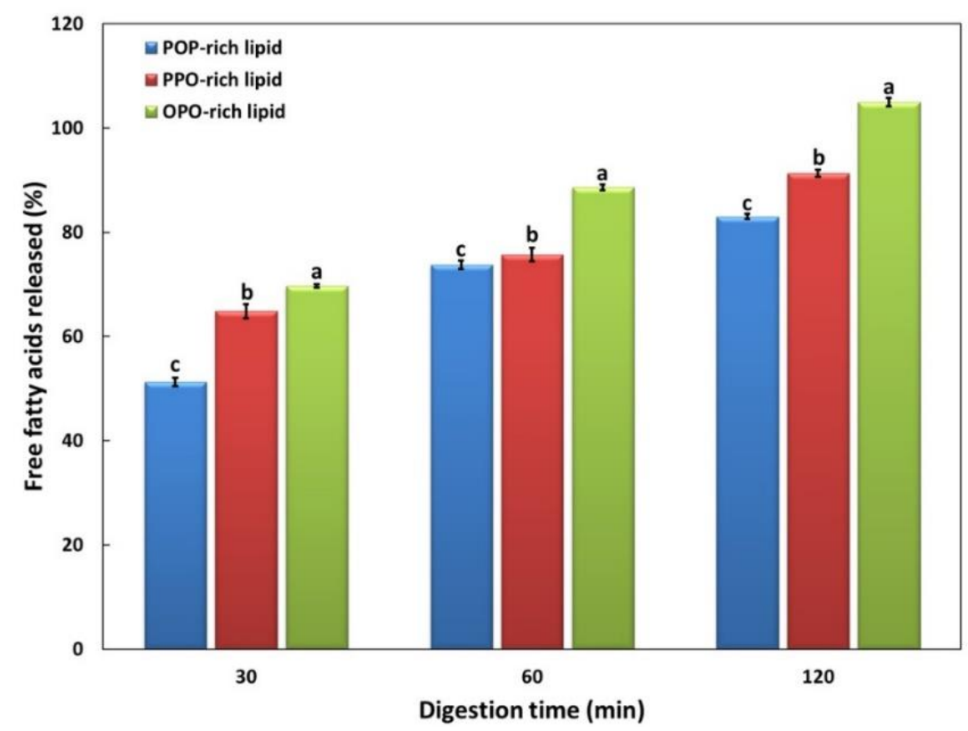

Figure 5. Free fatty acid released (\%) by POP-rich lipid, PPO-rich lipid, and OPO-rich lipid during in vitro multi-step digestion model at 30,60, and $120 \mathrm{~min} .{ }^{\mathrm{a}-\mathrm{c}}$ Means with different letters above the bars at the same digestion time are significantly different at $p<0.05$ by Duncan's multiple range test. Mean $\pm \mathrm{SD}(n=3)$.

The pancreatic lipase used in the in vitro digestion model was $s n-1,3$ regiospecific lipase, which breaks down TAG into two FFA molecules and one 2-MAG molecule. Sn-1,3 regiospecific lipase has been reported to hydrolyze all FAs at the $s n-1,3$ position during digestion, but only $22 \%$ of FAs at the $s n-2$ position [10]. Lipids are hydrolyzed to different extents depending on their type (unsaturation and chain length) and location (sn-1,3, $s n-2)$ of incorporating FAs. The hydrolysis rate has been reported to be higher for shortchain fatty acids (SCFAs) and USFAs than for long-chain fatty acids (LCFAs) and SFAs, respectively [9]. The hydrolysis rates of major FAs at the $s n-1,3$ positions were predicted to be high in the following order: $\mathrm{O}>\mathrm{P}>\mathrm{S}$. In the present study, the OPO-rich lipids had high $\mathrm{O}$ contents and thus, higher levels of released FAs. Their hydrolysis rates were high in the following order: OPO-rich > PPO-rich > POP-rich lipids.

There is increasing evidence that the melting point affects the rate of lipid digestion. Steele and Moore [30] fed sheep a diet containing myristic acid (purity 95\%), palmitic acid (96\%), and stearic acid (94\%) as lipid sources and measured their apparent digestibility based on the levels of secreted fecal lipids to compare the relationship between the melting point of each FA and its digestibility coefficient. They found that the higher the melting point of the FA, the lower the digestibility coefficient. Long-chain saturated FAs have low absorption coefficients as their melting points are higher than the body temperature and can show reduced digestibility as they form insoluble salts with calcium [10]. The CMPs of the POP-rich, PPO-rich, and OPO-rich lipids were $29.5,27.5$, and $18.5^{\circ} \mathrm{C}$, respectively, and the in vitro digestion degrees of these lipids increased as their melting points decreased.

\subsection{Acylglycerol Composition of the Hydrolyzed Lipids during the In Vitro Multi-Step Digestion Model}

The acylglycerol compositions of the hydrolyzed POP-rich, PPO-rich, and OPO-rich lipids at 60 and $120 \mathrm{~min}$ of in vitro digestion were analyzed, quantified, and presented in $\mu \mathrm{mol}$ with TMS as a reference (Figure 6 and Table 5). Figure 6 shows the enlarged ${ }^{1} \mathrm{H}$ NMR spectra of POP-rich lipid, PPO-rich lipid, and OPO rich lipid at regions of between 3.8 to 5.5 ppm (signal of TAG: 5.27, 1,3-DAG: 4.09, 1,2-DAG: 5.08, 1-MAG: 3.94, 2-MAG: 4.93 ppm) [31-34]. The TAG content steadily and rapidly decreased, while the MAG and DAG contents increased at 60 min but decreased thereafter.

The PPO-rich lipid consisted of TAG $(848.12 \mu \mathrm{mol})$, DAG $(6.12 \mu \mathrm{mol})$, and MAG $(1.58 \mu \mathrm{mol})$. The TAG content significantly and rapidly decreased during in vitro digestion, and $15.33 \%$ and $11.91 \%$ of the TAGs remained at 60 and $120 \mathrm{~min}$ compared with before 
digestion, respectively $(p<0.05)$. The DAG and MAG contents increased after $60 \mathrm{~min}$ of in vitro digestion and decreased at $120 \mathrm{~min}$. The DAG and MAG contents significantly increased by $7.4-$ and 1.8 -fold at $120 \mathrm{~min}(p<0.05)$. The 1,3-DAG content was 1.6 times higher than the 1,2-DAG content before digestion; however, the 1,2-DAG content significantly increased to 3.2- and 2.7-fold that of the 1,3-DAG content at 60 and $120 \mathrm{~min}(p<0.05)$. The 1-MAG content was 3.8-fold higher than the 2-MAG content before digestion and 1.7 and 1.4 times higher than the 2-MAG content at 60 and $120 \mathrm{~min}$, respectively.
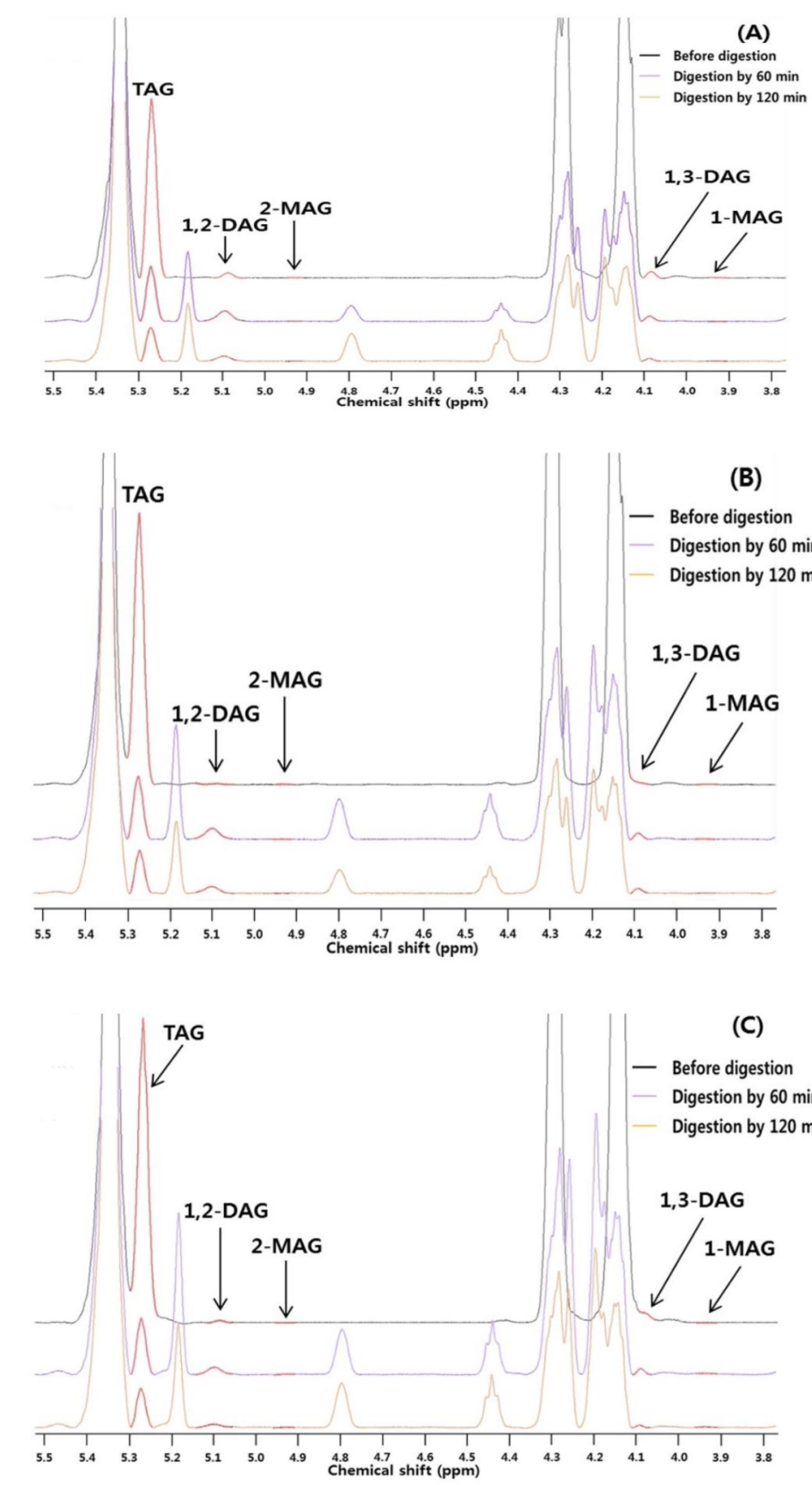

Figure 6. ${ }^{1} \mathrm{H}-\mathrm{NMR}$ spectrum of POP-rich lipid (A), PPO-rich lipid (B), and OPO-rich lipids (C) during the in vitro multi-step digestion model. Expanded regions between 3.8 and $5.5 \mathrm{ppm}$. Before digestion (black line), in vitro digestion by $60 \mathrm{~min}$ (purple line), and in vitro digestion by $120 \mathrm{~min}$ (orange line). 
The TAG content rapidly decreased in POP-rich lipids, resulting in $19.53 \%$ and $12.10 \%$ of the TAGs remaining at 60 and $120 \mathrm{~min}$ of in vitro digestion, respectively. The DAG content increased at $60 \mathrm{~min}$ and then decreased at $120 \mathrm{~min}(p<0.05)$, whereas the MAG content consistently increased $(p>0.05)$. The 1,3-DAG content was 1.1-fold higher than the 1,2-DAG content before digestion, but the 1,2-DAG content increased to 3.4- and 2.7-fold higher than the 1,3-DAG content at 60 and $120 \mathrm{~min}$, respectively. The TAG content of the OPO-rich lipid significantly decreased during digestion, resulting in $13.86 \%$ and $10.21 \%$ of the TAGs remaining at 60 and $120 \mathrm{~min}$, respectively $(p<0.05)$. The DAG and MAG contents increased at $60 \mathrm{~min}$ and decreased at $120 \mathrm{~min}(p<0.05)$. The 1,2-DAG content was 2.3- (at $60 \mathrm{~min}$ ) to 3.7-fold (at $120 \mathrm{~min}$ ) higher than the 1,3-DAG content. The 1-MAG content was 1.7-fold higher than the 2-MAG content at $60 \mathrm{~min}$ and similar at $120 \mathrm{~min}$.

TAGs are hydrolyzed by pancreatic lipase ( $s n-1,3$ position-specific enzyme) into 1,2DAG and FFA, and 1,2-DAG is then hydrolyzed into 2-MAG and FFA; these two processes occur simultaneously. During lipid digestion over time, TAGs, which had the highest levels among the acylglycerols, were mainly degraded at $60 \mathrm{~min}$, resulting in a transient increase in the levels of DAGs and MAGs. At $120 \mathrm{~min}$, the produced DAGs and MAGs and the remaining TAGs were further hydrolyzed, leading to a consistent reduction in their levels and an increase in the FFA content. Since the hydrolysis rates of 1,3-DAGs and 1-MAGs were higher than those of 1,2-DAGs and 2-MAGs, respectively, due to the $s n-1,3$ specificity of pancreatic lipase, the levels of 1,3-DAGs and 1-MAGs decreased more significantly than those of 1,2-DAGs and 2-MAGs. The change of acylglycerol composition of in vitro digested sunflower and soybean oils showed a similar result of this study. Nieva-Echevarría et al. [34] reported that the TAG content of sunflower oil decreased after digestion compared to before digestion, and that the 1,2-DAG content increased and then decreased during digestion. Martin-Rubio et al. [35] reported that, after in vitro digestion of soybean oil, the TAG content decreased, while the 1,2-DAG and 1,3-DAG contents increased, and that the 1,2-DAG content was higher than the 1,3-DAG content, showing a similar trend to the results of this study.

The concentrations of the remaining TAGs at 60 and $120 \mathrm{~min}$ of digestion were in the following order: POP-rich $>$ PPO-rich $>$ and OPO-rich lipids. Therefore, it was predicted that the digestion degree would be high in the order of OPO-rich > PPO-rich $>$ and POP-rich lipids, similar to the released FFA (\%) (Figure 5).

\subsection{Triacylglycerol Compositions of the Hydrolyzed Lipids during In Vitro Multi-Step Digestion}

Each TAG of the hydrolyzed lipids rapidly decreased at 30,60, and $120 \mathrm{~min}$ of in vitro digestion, whereas FFAs increased (Table 6 and Figure 7). OPO (MoSaMo), PPO (SaSaMo), and POP (SaMoSa), which are the major TAGs of OPO-rich, PPO-rich, and POP-rich lipids, respectively, decreased with digestion time, and the concentrations of the remaining TAGs were high in the following order: POP $(43.53 \%)>$ PPO $(15.79 \%)>$ OPO $(9.87 \%)$ at $30 \mathrm{~min}$, and POP $(20.97 \%)>$ PPO $(16.12 \%)>$ OPO $(7.29 \%)$ at $60 \mathrm{~min}$. This showed that the digestion degree of OPO was the highest, followed by those of PPO and POP. With a longer digestion time of $120 \mathrm{~min}$, the OPO content remained at 3.73\%, indicating that most of the OPO was hydrolyzed at the highest digestion degree (96.3\%), whereas the remaining PPO and POP contents at $120 \mathrm{~min}$ were $12.76 \%$ and $10.34 \%$, respectively, showing a greater increase in the digestion degree of POP than that of PPO between 60 and 120 min of digestion. 
Table 5. Acylglycerol compositions of POP-rich lipid, PPO-rich lipid, and OPO-rich lipids determined by the in vitro multi-step digestion model.

\begin{tabular}{|c|c|c|c|c|c|c|c|c|c|}
\hline \multirow{3}{*}{$\begin{array}{l}\text { Acylglycerol } \\
\text { ( } \mu \mathrm{mol})\end{array}$} & \multicolumn{3}{|c|}{ POP-Rich Lipid } & \multicolumn{3}{|c|}{ PPO-Rich Lipid } & \multicolumn{3}{|c|}{ OPO-Rich Lipid } \\
\hline & \multirow{2}{*}{ Before Digestion } & \multicolumn{2}{|c|}{ In Vitro Digestion } & \multirow{2}{*}{$\begin{array}{c}\text { Before } \\
\text { Digestion }\end{array}$} & \multicolumn{2}{|c|}{ In Vitro Digestion } & \multirow{2}{*}{$\begin{array}{c}\text { Before } \\
\text { Digestion }\end{array}$} & \multicolumn{2}{|c|}{ In Vitro Digestion } \\
\hline & & $60 \mathrm{~min}$ & $120 \mathrm{~min}$ & & $60 \mathrm{~min}$ & $120 \mathrm{~min}$ & & $60 \mathrm{~min}$ & $120 \mathrm{~min}$ \\
\hline $\begin{array}{l}\text { Diacylglycerol } \\
\text { (DAG) }\end{array}$ & $\begin{array}{c}54.96 \pm 1.52^{b} \\
(100 \%)\end{array}$ & $\begin{array}{c}68.97 \pm 3.69^{\mathrm{a}} \\
(125.49 \%)\end{array}$ & $\begin{array}{c}32.51 \pm 4.06^{c} \\
(59.15 \%)\end{array}$ & $\begin{array}{c}6.12 \pm 1.72^{b} \\
(100 \%)\end{array}$ & $\begin{array}{c}54.49 \pm 5.80^{\mathrm{a}} \\
(890.36 \%)\end{array}$ & $\begin{array}{c}45.07 \pm 2.79^{\mathrm{a}} \\
\quad(736.44 \%)\end{array}$ & $\begin{array}{c}4.79 \pm 0.14^{\mathrm{c}} \\
(100 \%)\end{array}$ & $\begin{array}{c}40.62 \pm 0.93^{\mathrm{a}} \\
(848.02 \%)\end{array}$ & $\begin{array}{c}15.24 \pm 2.65^{b} \\
(318.16 \%)\end{array}$ \\
\hline 1,3-DAG & $26.55 \pm 1.66^{\mathrm{a}}$ & $15.67 \pm 1.86^{b}$ & $8.52 \pm 0.02^{c}$ & $3.57 \pm 0.46^{b}$ & $12.87 \pm 1.68^{\mathrm{a}}$ & $12.22 \pm 0.26^{\mathrm{a}}$ & $2.48 \pm 0.05^{b}$ & $12.21 \pm 0.32^{\mathrm{a}}$ & $3.25 \pm 0.42^{b}$ \\
\hline $\begin{array}{l}\text { Monoacylglycerol } \\
\text { (MAG) }\end{array}$ & $\begin{array}{c}2.30 \pm 0.26^{\mathrm{a}} \\
(100 \%)\end{array}$ & $\begin{array}{c}2.43 \pm 0.22^{\mathrm{a}} \\
(105.65 \%)\end{array}$ & $\begin{array}{c}3.21 \pm 0.86^{\mathrm{a}} \\
(139.57 \%)\end{array}$ & $\begin{array}{c}1.58 \pm 0.01^{b} \\
(100 \%)\end{array}$ & $\begin{array}{c}4.20 \pm 0.81^{\mathrm{a}} \\
(265.82 \%)\end{array}$ & $\begin{array}{c}2.86 \pm 0.34 \mathrm{ab} \\
(181.01 \%)\end{array}$ & $\begin{array}{c}0.58 \pm 0.08^{b} \\
(100 \%)\end{array}$ & $\begin{array}{c}5.82 \pm 1.79^{\mathrm{a}} \\
(1003.45 \%)\end{array}$ & $\begin{array}{c}3.84 \pm 0.11 \mathrm{ab} \\
(662.07 \%)\end{array}$ \\
\hline 1-MAG & $1.08 \pm 0.03^{\mathrm{a}}$ & $1.36 \pm 0.18^{a}$ & $1.85 \pm 0.50^{\mathrm{a}}$ & $1.25 \pm 0.06^{\mathrm{b}}$ & $2.65 \pm 0.67^{\mathrm{a}}$ & $1.68 \pm 0.05^{\mathrm{ab}}$ & $0.15 \pm 0.01^{\mathrm{b}}$ & $3.64 \pm 1.27^{\mathrm{a}}$ & $1.87 \pm 0.29 \mathrm{ab}$ \\
\hline 2-MAG & $1.22 \pm 0.22^{\mathrm{a}}$ & $1.07 \pm 0.05^{\mathrm{a}}$ & $1.37 \pm 0.36^{\mathrm{a}}$ & $0.33 \pm 0.05^{\mathrm{b}}$ & $1.55 \pm 0.14^{\mathrm{a}}$ & $1.18 \pm 0.29^{a}$ & $0.43 \pm 0.07^{b}$ & $2.18 \pm 0.52^{\mathrm{a}}$ & $1.97 \pm 0.18^{a}$ \\
\hline
\end{tabular}

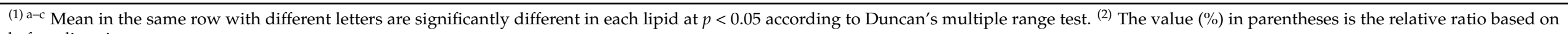
before digestion. 
Table 6. Triacylglycerol compositions of POP-rich, PPO-rich, and OPO-rich lipids during in vitro multi-step digestion analyzed with Ag-HPLC.

\begin{tabular}{|c|c|c|c|c|c|c|c|c|c|c|c|c|}
\hline \multirow{3}{*}{$\begin{array}{l}\text { Triacylglycerol (1) } \\
\text { (Area of Total } \\
\text { Triacylglycerol) }\end{array}$} & \multicolumn{4}{|c|}{ POP-Rich Lipid } & \multicolumn{4}{|c|}{ PPO-Rich Lipid } & \multicolumn{4}{|c|}{ OPO-Rich Lipid } \\
\hline & \multirow{2}{*}{ Before Digestion } & \multicolumn{3}{|c|}{ In Vitro Digestion } & \multirow{2}{*}{$\begin{array}{c}\text { Before } \\
\text { Digestion }\end{array}$} & \multicolumn{3}{|c|}{ In Vitro Digestion } & \multirow[t]{2}{*}{$\begin{array}{c}\text { Before } \\
\text { Digestion }\end{array}$} & \multicolumn{3}{|c|}{ In vitro Digestion } \\
\hline & & $30 \mathrm{~min}$ & $60 \mathrm{~min}$ & $120 \mathrm{~min}$ & & $30 \mathrm{~min}$ & $60 \mathrm{~min}$ & $120 \mathrm{~min}$ & & $30 \mathrm{~min}$ & $60 \mathrm{~min}$ & $120 \mathrm{~min}$ \\
\hline $\begin{array}{l}\text { SaMoSa } \\
\text { (POP) }\end{array}$ & $\begin{array}{c}16493 \pm 3410^{\mathrm{a}(4)} \\
(100 \%)^{(5)}\end{array}$ & $\begin{array}{c}7180 \pm 2538 \mathrm{~b} \\
(43.53 \%)\end{array}$ & $\begin{array}{c}3458 \pm 1772^{\mathrm{b}} \\
(20.97 \%)\end{array}$ & $\begin{array}{c}1705 \pm 278^{b} \\
(10.34 \%)\end{array}$ & $\begin{array}{c}284 \pm 4^{\mathrm{a}} \\
(100 \%)\end{array}$ & $\begin{array}{l}43 \pm 16^{\mathrm{b}} \\
(15.14 \%)\end{array}$ & $\begin{array}{l}40 \pm 9^{\mathrm{b}} \\
(14.08 \%)\end{array}$ & $\begin{array}{l}54 \pm 9^{b} \\
(19.01 \%)\end{array}$ & $\begin{array}{c}339 \pm 55 *(6) \\
(100 \%)\end{array}$ & $\begin{array}{c}28 \pm 1 \\
(8.26 \%)\end{array}$ & - & - \\
\hline $\begin{array}{l}\text { SaSaMo } \\
\text { (PPO) }\end{array}$ & $\begin{array}{c}1403 \pm 261^{\mathrm{a}} \\
(100 \%)\end{array}$ & $\begin{array}{c}457 \pm 196^{\mathrm{b}} \\
(32.57 \%)\end{array}$ & $\begin{array}{c}132 \pm 97 \mathrm{~b} \\
(9.41 \%)\end{array}$ & $\begin{array}{c}69 \pm 11^{\mathrm{b}} \\
(4.92 \%)\end{array}$ & $\begin{array}{c}37079 \pm 3403^{\mathrm{a}} \\
(100 \%)\end{array}$ & $\begin{array}{l}5855 \pm 2899 \mathrm{~b} \\
(15.79 \%)\end{array}$ & $\begin{array}{c}5977 \pm 188^{\mathrm{b}} \\
(16.12 \%)\end{array}$ & $\begin{array}{c}4730 \pm 3071 \mathrm{~b} \\
(12.76 \%)\end{array}$ & $\begin{array}{c}4756 \pm 594^{a} \\
(100 \%)\end{array}$ & $\begin{array}{c}416 \pm 70^{\mathrm{b}} \\
(8.75 \%)\end{array}$ & $\begin{array}{c}289 \pm 23^{b} \\
(6.08 \%)\end{array}$ & $\begin{array}{c}187 \pm 28^{\mathrm{b}} \\
(3.93 \%)\end{array}$ \\
\hline $\begin{array}{l}\text { SaDSa } \\
\text { (PLP) }\end{array}$ & $\begin{array}{c}1468 \pm 222^{\mathrm{a}} \\
(100 \%)\end{array}$ & $\begin{array}{c}610 \pm 202^{\mathrm{b}} \\
(41.55 \%)\end{array}$ & $\begin{array}{c}258 \pm 141^{\mathrm{b}} \\
(17.57 \%)\end{array}$ & $\begin{array}{c}142 \pm 59^{\mathrm{b}} \\
(9.67 \%)\end{array}$ & $\begin{array}{c}211 \pm 18^{\mathrm{a}} \\
(100 \%)\end{array}$ & $\begin{array}{l}29 \pm 3^{\mathrm{b}} \\
(13.74 \%)\end{array}$ & $\begin{array}{l}36 \pm 9^{\mathrm{b}} \\
(17.06 \%)\end{array}$ & $\begin{array}{l}27 \pm 3^{b} \\
(12.80 \%)\end{array}$ & $37 \pm 7$ & - & - & - \\
\hline $\begin{array}{l}\text { SaSaD/SaMoMo } \\
\text { (PPL/POO) }\end{array}$ & - & - & - & - & $\begin{array}{c}1226 \pm 145^{\mathrm{a}} \\
(100 \%)\end{array}$ & $\begin{array}{c}195 \pm 17^{\mathrm{b}} \\
(15.91 \%)\end{array}$ & $\begin{array}{c}169 \pm 15^{\mathrm{b}} \\
(13.78 \%)\end{array}$ & $\begin{array}{c}160 \pm 37^{\mathrm{b}} \\
(11.70 \%)\end{array}$ & $\begin{array}{c}4047 \pm 800^{\mathrm{a}} \\
(100 \%)\end{array}$ & $\begin{array}{c}432 \pm 263^{\mathrm{b}} \\
(10.67 \%)\end{array}$ & $\begin{array}{c}332 \pm 48^{\mathrm{b}} \\
(8.20 \%)\end{array}$ & $\begin{array}{c}178 \pm 43^{\mathrm{b}} \\
(4.40 \%)\end{array}$ \\
\hline $\begin{array}{l}\text { MoSaMo } \\
\text { (OPO) }\end{array}$ & $\begin{array}{c}5172 \pm 741 \text { a } \\
\quad(100 \%)\end{array}$ & $\begin{array}{c}2077 \pm 763^{\mathrm{b}} \\
(40.16 \%)\end{array}$ & $\begin{array}{c}830 \pm 610^{\mathrm{b}} \\
(16.05 \%)\end{array}$ & $\begin{array}{c}523 \pm 155^{b} \\
(10.11 \%)\end{array}$ & $\begin{array}{c}3728 \pm 278^{a} \\
(100 \%)\end{array}$ & $\begin{array}{c}550 \pm 136^{\mathrm{b}} \\
(14.75 \%)\end{array}$ & $\begin{array}{c}548 \pm 68^{\mathrm{b}} \\
(14.70 \%)\end{array}$ & $\begin{array}{c}436 \pm 262^{\mathrm{b}} \\
(11.70 \%)\end{array}$ & $\begin{array}{c}11,019 \pm 2963 \text { a } \\
(100 \%)\end{array}$ & $\begin{array}{c}1088 \pm 124^{\mathrm{b}} \\
(9.87 \%)\end{array}$ & $\begin{array}{c}803 \pm 222 \mathrm{~b} \\
(7.29 \%)\end{array}$ & $\begin{array}{c}411 \pm 124^{\mathrm{b}} \\
(3.73 \%)\end{array}$ \\
\hline $\begin{array}{l}\text { SaDMo/SaMoD } \\
\text { (PLO/POL) }\end{array}$ & $720 \pm 42$ & - & - & - & - & - & - & - & $155 \pm 6$ & - & - & - \\
\hline $\begin{array}{l}\text { MoMoMo } \\
\text { (OOO) }\end{array}$ & $149 \pm 37$ & - & - & - & $347 \pm 4$ & - & - & - & $1482 \pm 291$ & - & - & - \\
\hline Unknown & - & $3457 \pm 1027^{a}$ & $5244 \pm 578^{a}$ & $6898 \underset{\mathrm{a}}{ \pm} 1633$ & - & $1004 \pm 429^{b}$ & $2606 \underset{\mathrm{ab}}{ \pm} 216$ & $4444 \pm 1215^{\mathrm{a}}$ & - & $1148 \pm 86^{\mathrm{b}}$ & $1955 \pm 287$ & $4564 \pm 1601^{\mathrm{a}}$ \\
\hline $\mathrm{FFA}^{(7)}$ & - & $4678 \pm 368^{b}$ & $5515 \pm 1139^{b}$ & $8486 \pm 255^{a}$ & - & $11,154 \pm 3465^{a}$ & $\underset{\mathrm{a}}{12,298} \pm 714$ & $15,923 \pm 688^{a}$ & - & $\begin{array}{l}18,293 \pm \\
2863^{\mathrm{b}}\end{array}$ & $\begin{array}{c}26,264 \pm \\
4074^{\mathrm{ab}}\end{array}$ & $30,650 \pm \underset{\mathrm{a}}{ \pm} 4044$ \\
\hline
\end{tabular}

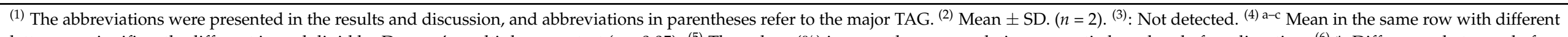

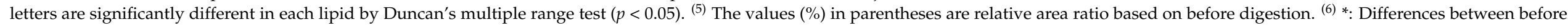
digestion and 30 min-digested lipid are significantly different by Student's $t$-test $(p<0.05) .{ }^{(7)}$ FFA: Free fatty acids. 

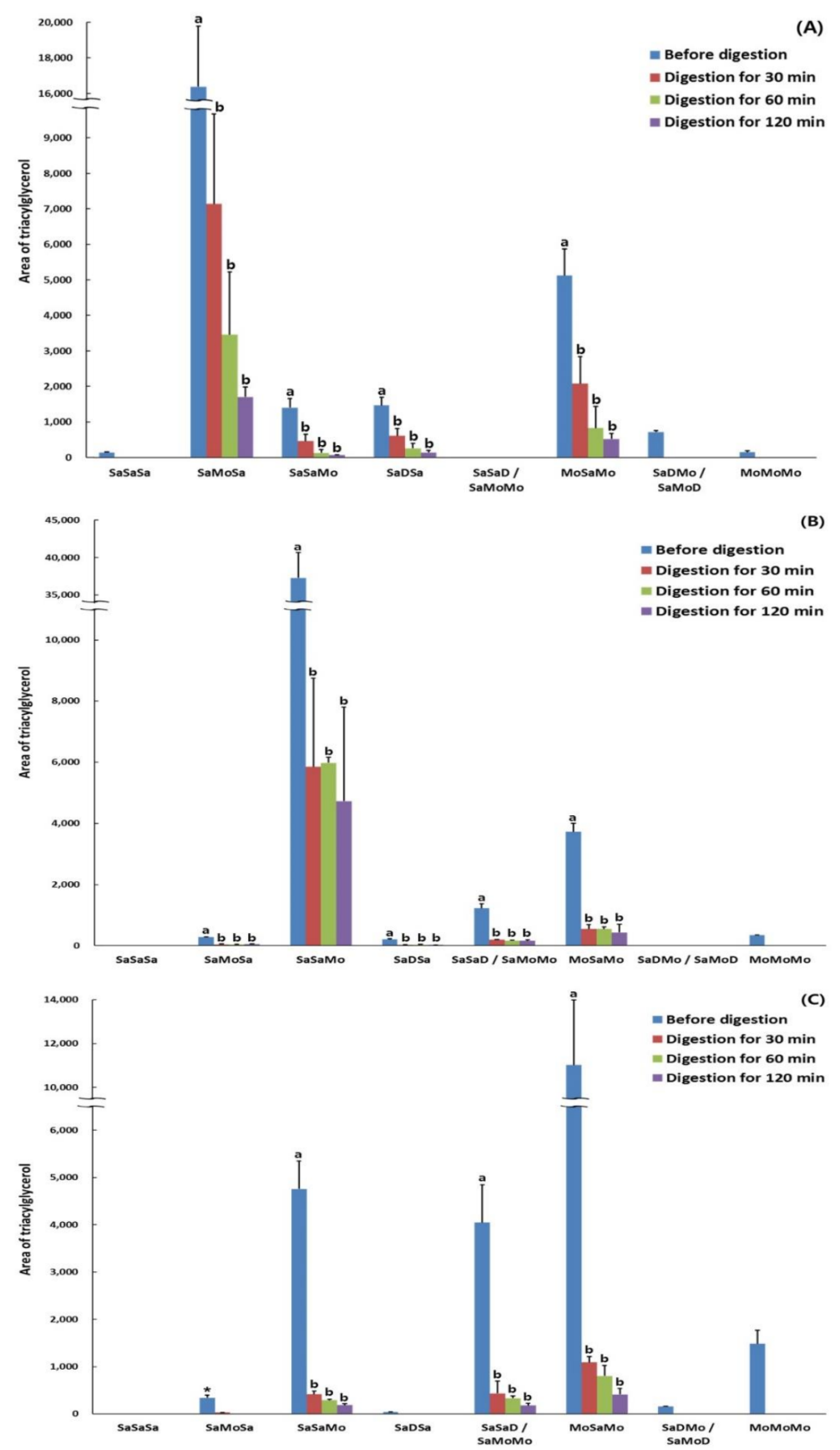

Figure 7. The major triacylglycerol compositions of POP-rich (A), PPO-rich (B), and OPO-rich lipids (C) determined during in vitro multi-step digestion analyzed with Ag-HPLC. a,b Means with different letters above the bars at the same digested lipids are significantly different by Duncan's multiple range test $(p<0.05)$. ${ }^{*}$ Differences between before digestion and 30 min-digested lipids are significantly different by Student's $t$-test $(p<0.05)$. Mean $\pm \mathrm{SD}(n=3)$.

Since the FA hydrolysis rate by pancreatic lipase was high in the order of $\mathrm{O}>\mathrm{P}>\mathrm{S}$, the rate of digestion for TAGs was predicted to be high in the following order: $\mathrm{OPO}>$ $\mathrm{PPO}>\mathrm{POP}$. However, POP showed a greater increase in the digestion degree compared to PPO at a digestion time of $120 \mathrm{~min}$, indicating that the digestion degree consistently increased over time as hydrolysis occurred, even if the initial digestion degree was low (digestion rate, $60 \mathrm{~min} \rightarrow 120 \mathrm{~min}$; POP, 79.0\% $\rightarrow$ 89.7\%; PPO, 83.9\% $\rightarrow$ 87.2\%). Similar to the results of this study, a previous study investigating the in vitro hydrolysis rate of triolein (TO), tridocosahexaenoyl glycerol (TriDHA), and trieicosapentaenoyl glycerol 
(TriEPA) by pancreatic lipase reported that during the initial digestion within 10 min, more than $70 \%$ of TO was hydrolyzed rapidly, whereas TriDHA and TriEPA were hydrolyzed slowly by about $30 \%$ but increased markedly afterwards. In the end, most of the TriEPA and $80 \%$ of TriDHA and TO were hydrolyzed, and TriEPA showed a higher hydrolysis rate than TO [36].

\section{Materials and Methods}

\subsection{Materials}

Palm stearin was provided by Samyang Co., Ltd. (Seoul, Korea). Soybean oil was purchased from Ottogi Co., Ltd. (Pyeongteak-city, Korea). Lipase from porcine pancreas, oleic acid, bile salts, pancreatin from porcine pancreas, PPP standard, and Supelco 37 component FAME mix were purchased from Sigma-Aldrich Co., Ltd. (St. Louis, MO, USA). Lipozyme RMIM was purchased from Novozymes (Bagsvaerd, Denmark), and triundecanoin was purchased from NU-CHEK PREP, Inc. (Elysian, MN, USA).

\subsection{Production of PPP-Rich and POP-Rich Lipids}

PPP-rich and POP-rich lipids were prepared from palm stearin by acetone fractionation, as shown in Figure 1. Palm stearin was completely melted, mixed with acetone $(1: 9, w t / v o l)$, and then placed at $28{ }^{\circ} \mathrm{C}$ for $18 \mathrm{~h}$. The fractionated acetone mixture was separated into solid and liquid phases by filtration using filter paper (Whatman No. 4, GE Healthcare, Amersham, UK). The separated solid phase (PPP-rich lipid) and liquid phase (POP-rich lipid) were concentrated in a rotary vacuum evaporator (N-1110, Sunileyela, Seongnam-city, Korea) and then dried with $\mathrm{N}_{2}$.

\subsection{Production of PPO-Rich and OPO-Rich Lipids}

PPP-rich lipid (213.18 g) and oleic acid (219.9 g) (1:3 molar ratio) were completely melted in an Erlenmeyer flask with a lid and placed in a water bath $\left(>80{ }^{\circ} \mathrm{C}\right)$. Lipozyme RMIM $(10 \%$ of substrate, $w / w)$ and $n$-hexane $(50 \mathrm{~mL})$ were added, and the lipase-catalyzed acidolysis reaction was performed in a shaking water bath (Daihan Labtech Co., Namyangju, Korea) at $200 \mathrm{rpm}$ and $55^{\circ} \mathrm{C}$ for $6 \mathrm{~h}$. After removing the enzyme by filtration, the reaction mixture was deacidified with $2 \mathrm{~N} \mathrm{KOH}$ and $0.1 \%$ phenolphthalein, concentrated using a vacuum evaporator, and dried with $\mathrm{N}_{2}$. The deacidified lipid was fractionated with acetone $(1: 5, w / v)$ at $9^{\circ} \mathrm{C}$ for $24 \mathrm{~h}$ and separated into solid and lipid phases. The liquid phase was mixed again with acetone $(1: 5, w / v)$ and fractionated at $5^{\circ} \mathrm{C}$ for $24 \mathrm{~h}$. After centrifugation $\left(3134 \times g, 5 \mathrm{~min}\right.$, and $\left.5^{\circ} \mathrm{C}\right)$, the solid phase (PPO-rich lipid) and liquid phase (OPO-rich lipid) were obtained, concentrated using a vacuum evaporator, and dried with $\mathrm{N}_{2}$. MAG and DAG were removed from the lipids by washing with methanol $(30 \mathrm{~min}$, repeated six times), and TAG was obtained. The purity of the TAG was confirmed by thin-layer chromatography (TLC) using $n$-hexane: diethyl ether: acetic acid (90:10:1, v/v/v).

\subsection{Analysis of Acylglycerol Composition with ${ }^{1}$ H-Nuclear Magnetic Resonance (NMR)}

Lipids (10 mg) were dissolved in $0.1 \%$ TMS in $\mathrm{CDCl}_{3}(100 \mu \mathrm{L})$ and placed in a $5 \mathrm{~mm}$ NMR tube (Norell, Landisville, NJ, USA). The acylglycerol composition was analyzed using a Bruker Advance III $600 \mathrm{MHz}$ NMR spectrometer (Bruker Corporation, Billerica, MA, USA), and the signals of TAG, DAG, MAG, and TMS from ${ }^{1} \mathrm{H}-\mathrm{NMR}$ spectra were identified [31-34]. TMS was used as a reference to calculate the TAG, DAG, and MAG of each lipid in $\mu \mathrm{mol}$ or $\mathrm{mmol} \%$ units.

\subsection{Analysis of TAG Composition with Silver Ion-High Performance Liquid Chromatography (Ag-HPLC)}

TAGs of the lipids were separated using an Ag-HPLC (Younglin, Anyang, Korea) equipped with a silver ion column (Chromspher 5 lipids, $250 \times 4.6 \mathrm{~mm}$ i.d., $5.0 \mu \mathrm{m}$, Varian, Middleburg, Netherlands) and an evaporative light scattering detector (ELSD, Sedex 75, Sedere, Alfortville, France). The temperature of the ELSD was set at $40{ }^{\circ} \mathrm{C}$, and $\mathrm{N}_{2}$ was 
used as a nebulizing gas at a pressure of 2.2 bar. Lipids were dissolved in chloroform: $n$-hexane $(1: 1, v / v)$ and $20 \mu \mathrm{L}$ were injected into the HPLC system. The mobile phases were solvent $\mathrm{A}$ ( $n$-hexane: isopropanol: acetonitrile $=100: 0.1: 0.1, v / v / v)$ and solvent $\mathrm{B}$ ( $n$-hexane: iso-propanol: acetonitrile $=100: 1: 1, v / v / v)$ at a flow rate of $1.5 \mathrm{~mL} / \mathrm{min}$. TAG separation was started with solvent A for $5 \mathrm{~min}$; the solvent ratio was increased to 80:20 $(v / v)$ for $10 \mathrm{~min}$, to $50: 50(v / v)$ for $10 \mathrm{~min}$, held for $1 \mathrm{~min}$, then returned to the initial condition of solvent A (100\%), and finally held for $8 \mathrm{~min}$. The TAGs were separated by the number of double bonds and the position of double bonds in the acyl chains, and the regioisomeric and enantiomeric isomers [37]. The individual TAG peaks in the HPLC chromatogram were identified by standard PPP, and designated by comparing the AgHPLC peaks of the OPO human milk fat substitute reported in Lee et al. [13], and TAG species reported in Hong et al. [38], which presented the Ag-HPLC chromatographs with the same methodology as the present study. Each TAG was presented with HPLC peak area or percentage $(\%)$ of total TAGs area.

\subsection{Analysis of Fatty Acid Composition}

The lipid $(25 \mathrm{mg})$ was mixed with $0.5 \mathrm{~N}$ methanolic $\mathrm{NaOH}(1.5 \mathrm{~mL})$ and saponified at $85{ }^{\circ} \mathrm{C}$ for $10 \mathrm{~min}$. After cooling, $\mathrm{BF}_{3}$-methanol $(2 \mathrm{~mL})$ was added, and methylated at $85^{\circ} \mathrm{C}$ for $10 \mathrm{~min}$. The FA composition was analyzed using a gas chromatography (GC-2010 Plus, Shimadzu Corp., Kyoto, Japan) equipped with a flame ionization detector, and an $\mathrm{SP}^{\mathrm{TM}}-2560$ capillary column $(100 \mathrm{~m} \times 0.25 \mathrm{~mm} \times 0.2 \mu \mathrm{m}$ film thickness, Supelco Inc., Bellefonte, PA, USA) [39]. The oven temperature was held at $100{ }^{\circ} \mathrm{C}$ for $5 \mathrm{~min}$, increased to $240{ }^{\circ} \mathrm{C}$ at $4{ }^{\circ} \mathrm{C} / \mathrm{min}$, and maintained for $40 \mathrm{~min}$. The temperatures of the injector and detector were 250 and $260{ }^{\circ} \mathrm{C}$, respectively, and the carrier gas and column flow were $\mathrm{N}_{2}$ and $1 \mathrm{~mL} / \mathrm{min}$, respectively. Triundecanoin was used as an internal standard, and Supelco 37 component FAME mix was used as an external standard. After obtaining the GC chromatogram, each FA was identified by comparison with the peaks of the Supelco 37 component FAME mix and the area of each peak was expressed as a percentage of the total FAs.

For analysis of the positional FA composition, lipid (25 mg), pancreatic lipase (25 mg), $0.05 \%$ bile salt $(6.25 \mathrm{~mL}), 2.2 \% \mathrm{CaCl}_{2}(2.5 \mathrm{~mL})$, and Tris- $\mathrm{HCl}$ buffer $(\mathrm{pH} 7.6,25 \mathrm{~mL}$ ) were mixed in a test tube and reacted for $3 \mathrm{~min}$ at $37^{\circ} \mathrm{C}$, with 30 -s vortexing, and repeated three times. Then, $6 \mathrm{~mL}$ of diethyl ether were mixed for $1 \mathrm{~min}$ and centrifuged $(1224 \times g, 5 \mathrm{~min})$. The supernatant was concentrated with $\mathrm{N}_{2}$ and the hydrolyzed lipid was separated into TAG, 1,3-DAG, 1,2-DAG, 1-MAG, and 2-MAG on a TLC F 254 silica plate (Merck, Kenilworth, NJ, USA) with a developing solvent ( $n$-hexane: diethyl ether: acetic acid $=50: 50: 1, v / v / v$ ). The band presenting 2-MAG was taken from the TLC plate, and was saponified and methylated. The FA composition of 2-MAG was analyzed with GC, and the FA composition of the $s n-1,3$ position was calculated with Equation (1):

FA composition at $s n-1,3$ position $(\%)=[3 \times$ total FA composition $(\%)-$ FA composition at $s n-2(\%)] / 2$.

\subsection{Analysis of Melting and Crystallization Properties with Differential Scanning Calorimetry (DSC)}

The SMPs and CMPs of the lipids were measured using the capillary tube method of the AOCS Official Method Cc 1-25 [40]. The melting and crystallization properties were analyzed using DSC (DSC-8000, Perkin Elmer, Waltham, MA, USA). The sample was accurately weighed $(7 \pm 0.1 \mathrm{mg})$ on a DSC aluminum pan, and an empty aluminum pan was used as a reference. The sample was heated to $80^{\circ} \mathrm{C}$ and held for $10 \mathrm{~min}$. The crystallization thermogram was obtained by cooling to $-60^{\circ} \mathrm{C}$ at a rate of $10^{\circ} \mathrm{C} / \mathrm{min}$, and after holding for $10 \mathrm{~min}$, the melting thermogram was obtained by heating to $80^{\circ} \mathrm{C}$ at a rate of $5{ }^{\circ} \mathrm{C} / \mathrm{min}$. All samples were analyzed in triplicate. 


\subsection{Crystal Morphology by Polarized Light Microscopy}

The completely melted lipid $(20 \mu \mathrm{L})$ was placed on a preheated microscope glass slide and covered with a preheated cover slip. For crystallization of the lipid, the prepared slides were stored at $4{ }^{\circ} \mathrm{C}$ for $16 \mathrm{~h}$. The crystal morphology was observed using polarized light microscopy (Eclipase 50i POL, Nikon, Tokyo, Japan) and a digital camera (ISH 300, Tucsen Photonics Co., Ltd., Fuzhou, China).

\subsection{In Vitro Multi-Step Digestion Model}

The in vitro digestion degree of lipids was assessed using a modified method described by Versantvoort et al. [41] and Chang et al. [18] (Table 7). All simulated digestive juices were prepared and used on the day of the experiment, and their compositions are presented in Table 7 . The completely melted lipid $(100 \mathrm{mg})$ and saliva juice $(1.2 \mathrm{~mL})$ were mixed in an Erlenmeyer flask in a shaking water bath for $5 \mathrm{~min}$ at $37^{\circ} \mathrm{C}$ and $80 \mathrm{rpm}$, and gastric juice $(2.4 \mathrm{~mL})$ was added and allowed to react for $2 \mathrm{~h} . \mathrm{NaHCO}_{3}$ solution $(0.4 \mathrm{~mL})$, bile juice $(1.2 \mathrm{~mL})$, and duodenal juice $(2.4 \mathrm{~mL})$ were added, and the mixture was hydrolyzed for 30, 60, and $120 \mathrm{~min}$. After the reaction, a lipase inhibitor $(100 \mu \mathrm{L}, 0.2 \mathrm{~g}$ of 4-bromophenylboronic acid $/ \mathrm{mL}$ in methanol) was added to stop digestion [42]. For the extraction of hydrolyzed lipids, $n$-hexane was added, mixed, and centrifuged at $1763 \times g$ for $5 \mathrm{~min}$, and the supernatant was collected (repeated three times). Next, $1 \mathrm{~N} \mathrm{HCl}(0.5 \mathrm{~mL})$ was mixed with the remaining lower part for $1 \mathrm{~min}$, then $n$-hexane $(10 \mathrm{~mL})$ was mixed and centrifuged, and the supernatant was collected (repeated three times). The all $n$-hexane extraction was combined, and then the solvent was removed by using $\mathrm{N}_{2}$. Next, $10 \mathrm{~mL}$ of ethanol: $n$-hexane $(1: 1, v / v)$ and $1 \mathrm{~mL}$ of $1 \%$ phenolphthalein in ethanol were added and titrated with $0.05 \mathrm{~N} \mathrm{KOH}$ solution. The in vitro digestion degree of each lipid was expressed as the released FFA (\%) using Equation (2) [43]:

$$
\text { FFAs released }(\%)=\frac{\text { Volume of } \mathrm{KOH}(\mathrm{mL}) \times \text { Normality of } \mathrm{KOH}(\mathrm{N}) \times \text { Molecular weight of lipid }}{\text { Amount of lipid used digestion }(\mathrm{mg}) \times 2} \times 100
$$

Table 7. The composition of synthetic juices for the in vitro multi-step digestion model ${ }^{(1)}$.

\begin{tabular}{|c|c|c|c|c|}
\hline & Saliva Juice & Gastric Juice & Duodenal Juice & Bile Juice \\
\hline Inorganic solution & 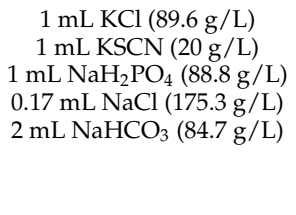 & 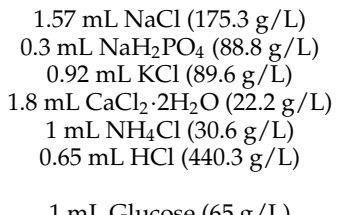 & $\begin{array}{c}4 \mathrm{~mL} \mathrm{NaCl}(175.3 \mathrm{~g} / \mathrm{L}) \\
4 \mathrm{~mL} \mathrm{NaHCO}_{3}(84.7 \mathrm{~g} / \mathrm{L}) \\
1 \mathrm{~mL} \mathrm{KH}_{2} \mathrm{PO}_{4}(8 \mathrm{~g} / \mathrm{L}) \\
0.63 \mathrm{~mL} \mathrm{KCl}(89.6 \mathrm{~g} / \mathrm{L}) \\
1 \mathrm{~mL} \mathrm{MgCl}_{2}(5 \mathrm{~g} / \mathrm{L}) \\
0.9 \mathrm{~mL} \mathrm{CaCl}_{2} \cdot 2 \mathrm{H}_{2} \mathrm{O}(22.2 \mathrm{~g} / \mathrm{L}) \\
18 \mu \mathrm{LCl}(440.3 \mathrm{~g} / \mathrm{L})\end{array}$ & $\begin{array}{c}3 \mathrm{~mL} \mathrm{NaCl}(175.3 \mathrm{~g} / \mathrm{L}) \\
6.83 \mathrm{~mL} \mathrm{NaHCO} 3(84.7 \mathrm{~g} / \mathrm{L}) \\
0.42 \mathrm{~mL} \mathrm{KCl}(89.6 \mathrm{~g} / \mathrm{L}) \\
1 \mathrm{~mL} \mathrm{CaCl} \cdot 2 \mathrm{H}_{2} \mathrm{O}(22.2 \mathrm{~g} / \mathrm{L}) \\
15 \mu \mathrm{L} \mathrm{HCl}(440.3 \mathrm{~g} / \mathrm{L})\end{array}$ \\
\hline Organic solution & 0.8 mL Urea $(25 \mathrm{~g} / \mathrm{L})$ & $\begin{array}{c}1 \text { mL Glucose }(65 \mathrm{~g} / \mathrm{L}) \\
1 \mathrm{~mL} \text { Glucuronic acid }(2 \mathrm{~g} / \mathrm{L}) \\
0.34 \text { mL Urea }(25 \mathrm{~g} / \mathrm{L}) \\
1 \mathrm{~mL} \text { Glucosamine }(33 \mathrm{~g} / \mathrm{L})\end{array}$ & 0.4 mL Urea $(25 \mathrm{~g} / \mathrm{L})$ & 1 mL Urea $(25 \mathrm{~g} / \mathrm{L})$ \\
\hline $\begin{array}{l}\text { Supplementation to } \\
\text { the solution }\end{array}$ & $\begin{array}{l}\alpha \text {-amylase } 29 \mathrm{mg} \\
\text { Uric acid } 1.5 \mathrm{mg} \\
\text { Mucin } 2.5 \mathrm{mg}\end{array}$ & $\begin{array}{l}\text { BSA } 0.1 \mathrm{~g} \\
\text { Pepsin } 0.25 \mathrm{~g} \\
\text { Mucin } 0.3 \mathrm{~g}\end{array}$ & $\begin{array}{c}\text { BSA } 0.1 \mathrm{~g} \\
\text { Pancreatin } 0.9 \mathrm{~g} \\
\text { Lipase } 0.15 \mathrm{~g}\end{array}$ & $\begin{array}{l}\text { BSA } 0.18 \mathrm{~g} \\
\text { Bile salt } 3 \mathrm{~g}\end{array}$ \\
\hline $\mathrm{pH}$ & $6.8 \pm 0.2^{(2)}$ & $1.3 \pm 0.02$ & $8.1 \pm 0.2$ & $8.2 \pm 0.2$ \\
\hline
\end{tabular}

\subsection{Statistical Analysis}

Analysis of variance was performed using the Statistical Analysis System 9.4 (SAS Institute, Cary, NC, USA). The statistical significance of the experimental means was analyzed by Duncan's multiple range test and Student's $t$-test. A $p$ value $<0.05$ was considered significant.

\section{Conclusions}

PPP-rich, POP-rich, PPO-rich, and OPO-rich lipids with different regiospecific positions of palmitic acid were synthesized, and their physicochemical and digestion characteristics were compared. The PPP-rich, POP-rich, PPO-rich, and OPO-rich lipids contained 
PPP (81.2\%), POP (64.4\%), PPO (86.5\%), and OPO (50.2\%), respectively, as the major TAG. POP-rich and PPO-rich lipids have similar total fatty acid composition; however, the POPrich lipid had a higher palmitic acid content at the $s n-1,3$ position, and higher melting points, crystallization temperatures, and packing densities of fat crystals than PPO-rich lipid. The in vitro digestion degree analyzed by the released $\mathrm{FA}(\%)$ at 30, 60, and $120 \mathrm{~min}$ was followed by OPO-rich > PPO-rich > POP-rich lipids. As an individual TAG, POP (in POP-rich lipid) was hydrolyzed faster than PPO (in PPO-rich lipid) and OPO (in OPOrich lipid), showing the digestion extent by $92.3 \%, 89.7 \%$, and $87.2 \%$, respectively. This study confirmed that the content and incorporated position of palmitic acid in the TAG backbone affect the physicochemical and digestion properties. In addition, based on the established in vitro multi-step model for assessment of the digestion properties of specific TAG-enriched lipids in this study, an in vitro absorption study that predicts the absorption characteristics of lipids using Caco-2 cells will be required in the future.

Author Contributions: Conceptualization, methodology, validation, J.-H.L.; formal analysis, investigation, H.J.C.; writing—original draft preparation, H.-J.C.; writing—review and editing, J.-H.L.; visualization, H.-J.C. and J.-H.L. All authors have read and agreed to the published version of the manuscript.

Funding: This research was supported by the Basic Science Research Program through the National Research Foundation of Korea (NRF) funded by Ministry of Education (2018R1D1A1B0748481).

Institutional Review Board Statement: Not applicable.

Informed Consent Statement: Not applicable.

Data Availability Statement: Not applicable.

Conflicts of Interest: The authors declare no conflict of interest.

Sample Availability: Samples of the compounds are not available from the authors.

\section{References}

1. Baker, M.R.; Bouzidi, L.; Garti, N.; Narine, S.S. Multi-length-scale elucidation of kinetic and symmetry effects on the behavior of stearic and oleic TAG.II: OSO and SOO. J. Am. Chem. Soc. 2014, 91, 1685-1694. [CrossRef]

2. Marikkar, J.M.N.; Yanty, N.A.M.; Paciculli, M.; Miskandar, M.S.; Chiavaro, E. Composition and thermal properties of quaternary mixtures of palm oil: Palm stearin: Soybean oil: Cocoa butter. Ital. J. Food Sci. 2018, 30, 740-751.

3. Yuan, T.; Qi, C.; Dai, X.; Xia, Y.; Sun, C.; Sun, J.; Yu, R.; Zhou, Q.; Jin, Q.; Wei, W.; et al. Triacylglyerol composition of breast milk during different lactation stages. J. Agric. Food Chem. 2019, 67, 2272-2278. [CrossRef] [PubMed]

4. Koyano, T.; Hachlya, I. Phase behavior of mixed systems of SOS and OSO. J. Phys. Chem. 1992, 96, 10514-10520. [CrossRef]

5. Minato, A.; Ueno, S.; Yano, J.; Smith, K.; Seto, H.; Amemiya, Y.; Sato, K. Thermal and structural properties of sn-1,3-dipalmitoyl-2oleoylglycerol and $s n$-1,3-dioleoyl-2-palmitoylglycerol binary mixtures examined with synchrotron radiation X-ray diffraction. JAOCS 1997, 74, 1213-1220. [CrossRef]

6. Mohanan, A.; Darling, B.; Bouzidi, L.; Narine, S.S. Mitigating crystallization of saturated FAMES (FA methyl esters) in biodiesel. 3. The binary phase behavior of 1,3-dioleoyl-2-palmitoyl glycerol-methyl palmitate-A multi-length scale structural elucidation of mechanism responsible for inhibiting FAME crystallization. Energy 2015, 86, 500-513.

7. Boodhoo, M.V.; Bouzidi, L.; Narine, S.S. The binary phase behavior of 1,3-dipalmitoyl-2-stearoyl-sn-glycerol and 1,2-dipalmitoyl3-stearoyl-sn-glycerol. Chem. Phys. Lipids 2009, 160, 11-32. [CrossRef]

8. Lee, J.H.; Akoh, C.C.; Himmelsbach, D.S.; Lee, K.T. Preparation of interesterified plastic fats from fats and oils free of trans fatty acid. J. Agric. Food Chem. 2008, 56, 4039-4046. [CrossRef]

9. Michalski, M.C.; Genot, C.; Gayet, C.; Lopez, C.; Fin, F.; Joffre, F.; Vendeuvre, J.L.; Bouvier, J.; Chardigny, J.M.; Raynal-Ljutovac, K.; et al. Multiscale structures of lipids in foods as parameters affecting FA bioavailability and lipid metabolism. Prog. Lipid Res. 2013, 52, 354-373. [CrossRef]

10. Karupaiah, T.; Sundram, K. Effects of stereospecific positioning of FAs in triacylglycerol structures in native and randomized fats: A review of their nutritional implications. Nutr. Metab. 2007, 4, 1-17. [CrossRef]

11. Na, B.R.; Lee, J.H. In vitro and in vivo digestibility of soybean, fish, and microalgal oils, and their influences on fatty acid distribution in tissue lipid of mice. Molecules 2020, 25, 5357. [CrossRef]

12. Aoe, S.; Yamamura, J.; Matsuyama, H.; Hase, M.; Shiota, M.; Miura, S. The positional distribution of dioleoyl-palmitoyl glycerol influences lymph chylomicron transport, composition and size in rats. J. Nutr. 1997, 127, 1269-1273. [CrossRef]

13. Lee, J.H.; Son, J.M.; Akoh, C.C.; Kim, M.R.; Lee, K.T. Optimized synthesis of 1,3-dioleoyl-2-palmitoylglycerol-rich triacylglycerol via interesterification catalyzed by a lipase from Thermomyces Ianuginosus. New Biotechnol. 2010, 27, 38-45. [CrossRef] 
14. Son, J.M.; Lee, J.H.; Xue, C.L.; Hong, S.T.; Lee, K.T. Optimization of lipase-catalyzed interesterification for production of human milk fat substitutes by response surface methodology. Korean J. Food Sci. Technol. 2011, 43, 689-693. [CrossRef]

15. Wang, X.; Jiang, C.; Xu, W.; Miu, Z.; Jin, Q.; Wnag, X. Enzymatic synthesis of structured triacylglycerols rich in 1,3-dioeloyl-2palmitoylglycerol and 1-oleoyl-2-palmitoyl-3-linoleoylglycerol in a solvent free system. LWT 2020, 118, 108798. [CrossRef]

16. Bae, S.K.; Lee, K.S.; Lee, K.T. Synthesis of cocoa butter alternative from coconut oil fraction and palm oil fractions by lipasecatalyzed interesterification. J. Korean Soc. Food Sci. Nutr. 2010, 39, 1487-1494. [CrossRef]

17. Wei, W.; Feng, Y.; Zhang, X.; Cao, X.; Feng, F. Synthesis of structured lipid 1,3-dioleoyl-2-palmitoylglycerol in both solvent and solvent-free system. LWT 2015, 60, 1187-1194. [CrossRef]

18. Chang, H.J.; Na, B.R.; Lee, J.H. Hydrolytic properties of algae oil and DAG-rich algae oil using pH-stat and multi-step in vitro digestion models. J. Korean Soc. Food Sci. Nutr. 2018, 47, 1118-1127. [CrossRef]

19. Woo, J.M.; Lee, K.T. Comparison of hydrolysis from in vitro digestion using symmetric triacylglycerol compounds by enzymatic interesterification. J. Korean Soc. Food Sci. Nutr. 2014, 43, 842-853. [CrossRef]

20. McClements, D.J.; Li, Y. Review of in vitro digestion models for rapid screening of emulsion-based systems. Food Funct. 2010, 1, 32-59. [CrossRef]

21. Sams, L.; Paume, J.; Giallo, J.; Carrière, F. Relevant $\mathrm{pH}$ and lipase for in vitro models of gastric digestion. Food Funct. 2016, 7, 30-45. [CrossRef]

22. Minekus, M.; Alminger, M.; Alvito, P.; Sallancet, S.; Bohn, T.; Bourlieu, C.; Carrière, F.; Boutrou, R.; Corredig, M.; Dupont, D.; et al. A standardized static in vitro digestion method suitable for food-An international concensus. Food Funct. 2014, 5, 1113-1124. [CrossRef]

23. Brodkorb, A.; Egger, L.; Alminger, M.; Alvito, P.; Assunção, R.; Balance, S.; Bohn, T.; Bourlieu-Lacanal, C.; Boutrou, R.; Carrière, F.; et al. INFGEST static in vitro simulation of gastrointestinal food digestion. Nat. Protoc. 2019, 14, 991-1014. [CrossRef]

24. Yoon, S.H.; Choi, E.O.; Oh, C.H.; Song, Y.O.; Jung, M.W.; Hong, S.T.; Jang, P.S.; Lee, J.H.; Kim, H.J. FOOD LIPIDS, 1st ed.; SOOHAKSA: Seoul, Korea, 2015; pp. 365-370.

25. Sharma, A.; Sharma, S.D.; Buddhi, D. Accelerated thermal cycle test of acetamide, stearic acid and paraffin wax for solar thermal latent heat storage applications. Energy Convers. Manag. 2002, 43, 1923-1930. [CrossRef]

26. Garrett, R.L.; Young, R.J. Effect of micelle formation on the absorption of neutral fat and fatty acids by the chicken. J. Nutr. 1975, 105, 827-838. [CrossRef]

27. Wang, Y.; Callejo, R.; Slawin, A.M.Z.; O'Hagan, D. The difluoromethylene $\left(\mathrm{CF}_{2}\right)$ group in aliphatic chains: Synthesis and conformational preference of palmitic acids and nonadecane containing $\mathrm{CF}_{2}$ groups. Beilstein J. Org. Chem. 2014, 10, 18-25. [CrossRef]

28. Motoyama, M. Structure and phase characterization of triacylglycerols by raman spectroscopy. Bull NARO Inst. Livest. Grassl. Sci. 2012, 12, 19-68.

29. Gwie, G.G.; Griffiths, R.J.; Cooney, D.T.; Johns, M.L.; Wilson, D.I. Microstructures formed by spray freezing of food fats. JAOCS 2006, 83, 1053-1062. [CrossRef]

30. Steele, W.; Moore, J.H. The digestibility coefficients of myristic, palmitic and stearic acids in the diet of sheep. J. Dairy. Res. 1968, 35, 371-376. [CrossRef]

31. Guillén, M.D.; Uriatre, P.S. Study by ${ }^{1} \mathrm{H}$ NMR spectroscopy of the evolution of extra virgin olive oil composition submitted to frying temperature in an industrial fryer for a prolonged period of time. Food Chem. 2012, 134, 162-172. [CrossRef]

32. Hoffman, R.E. Standardization of chemical shifts of TMS and solvent signals in NMR solvents. Magn. Reson. Chem. 2006, 44, 606-616. [CrossRef] [PubMed]

33. Joyce, P.; Barnes, T.J.; Boyd, B.J.; Prestidge, C.A. Porous nanostructure controls kinetics, disposition and self-assembly structure of lipid digestion products. RSC Adv. 2016, 6, 78385-78395. [CrossRef]

34. Nieva-Echvarría, B.; Goicoechea, E.; Manzanos, M.J.; Guillén, M.D. Usefulness of ${ }^{1} \mathrm{H}-\mathrm{NMR}$ in assessing the extent of lipid digestion. Food Chem. 2015, 179, 182-190. [CrossRef] [PubMed]

35. Martin-Rubio, A.S.; Sopelana, P.; Guillén, M.D. Influence of minor components on lipid bioaccessibility and oxidation durting in vitro digestion of soybean oil. J. Sci. Food Agric. 2019, 99, 4793-4800. [CrossRef]

36. Ikeda, L.; Sasaki, E.; Yasunami, H.; Nomiyama, S.; Nakayama, M.; Sugano, M.; Imaizumi, K.; Yazawa, K. Digestion and lymphatic transport of eicosapentaenoic and docosahexaenoic acids given in the form of triacylglycerol, free acid and ethyl ester in rat. Biochim. Biophys. Acta 1995, 1259, 297-304. [CrossRef]

37. Momchilava, S.M.; Nikolova-Damyanova, B.M. Advances in silver ion chromatography for the analysis of fatty acids and triacylglycerols-2001 to 2011. Anal. Sci. 2012, 28, 837-844. [CrossRef]

38. Hong, J.S.; Shin, J.A.; Lee, K.T. Enzymatic reaction model for the production of symmetrical lipid moelcules using the response surface methodology. Korean J. Agric. Sci. 2018, 56, 265-282.

39. Qi, J.F.; Wang, X.Y.; Zhang, H.; Lee, J.H. Optimization of omega-3 enriched-diacylglycerol production by enzymatic esterification using a response surface methodology. Food Sci. Biotechnol. 2014, 23, 1129-1136. [CrossRef]

40. AOCS. Official Method and Recommended Practices, 6th ed.; American Oil Chemists' Society: Champaign, IL, USA, $2009 ;$ pp. 1-25. 
41. Versantvoort, C.H.M.; Oomen, A.G.; de Kamp, E.V.; Rompelberg, C.J.M.; Sips, A.J.A.M. Applicability of an in vitro digestion model in assessing the bioaccessibility of mycotoxins from food. Food Chem. Toxicol. 2005, 43, 31-40. [CrossRef]

42. Williams, H.D.; Sassene, P.; Kleberg, K.; Bakala-N'Goma, J.C.; Calderone, M.; Jannin, V.; Igonin, A.; Partheil, A.; Marchaud, D.; Jule, E.; et al. Toward the establishment of standardized in vitro tests for lipid-based formulations, part 1: Method parameterization and comparison of in vitro digestion profiles across a range of representative formulations. J. Pharm. Sci. 2012, 101, 3360-3380. [CrossRef]

43. Troncoso, E.; Aguilera, J.M.; McClements, D.J. Influence of particle size on the in vitro digestibility of protein-coated lipid nanoparticles. J. Colloid Interface Sci. 2012, 382, 110-116. [CrossRef] 